\title{
Pre-analytical issues in liquid biopsy - where do we stand?
}

https://doi.org/10.1515/labmed-2019-0167

Received October 1, 2019; accepted February 26, 2020; previously published online April 7, 2020

\begin{abstract}
It is well documented that in the chain from sample to the result in a clinical laboratory, the pre-analytical phase is the weakest and most vulnerable link. This also holds for the use and analysis of extracellular nucleic acids. In this short review, we will summarize and critically evaluate the most important steps of the pre-analytical phase, i.e. the choice of the best control population for the patients to be analyzed, the actual blood draw, the choice of tubes for blood drawing, the impact of delayed processing of blood samples, the best method for getting rid of cells and debris, the choice of matrix, i.e. plasma vs. serum vs. other body fluids, and the impact of longterm storage of cell-free liquids on the outcome. Even if the analysis of cell-free nucleic acids has already become a routine application in the area of non-invasive prenatal screening (NIPS) and in the care of cancer patients (search for resistance mutations in the EGFR gene), there are still many unresolved issues of the pre-analytical phase which need to be urgently tackled.
\end{abstract}

Keywords: cell-free nucleic acids; extracellular nucleic acids; liquid profiling; pre-analytical phase.

\section{Introduction}

Recently, new European Union regulations on medical devices and in vitro diagnostic medical devices entered into force and will apply fully for in vitro diagnostics in May 2022 [1]. The requirements for in vitro diagnostics will change significantly and will also include the definition of pre-analytical parameters.

\footnotetext{
*Correspondence: Michael Fleischhacker, DRK Kliniken Berlin Mitte, Klinik für Innere Medizin - Pneumologie und Schlafmedizin, Drontheimer Str. 39 - 40, 13359 Berlin, Germany, E-Mail: m.fleischhacker@drk-kliniken-berlin.de

Bernd Schmidt: DRK Kliniken Berlin Mitte, Klinik für Innere Medizin Pneumologie und Schlafmedizin, Berlin, Germany
}

The analysis of cell-free nucleic acids (which has misleadingly been coined liquid biopsy, more precisely would be "liquid profiling") may be useful in different areas, for the diagnosis of patients with different diseases and especially for cancer patients, treatment monitoring, tracking of minimal residual disease (early appearance of treatment resistance), and for the establishment of the prognosis for these patients. While the latter points might be within tangible reach, its usefulness as a diagnostic tool is still heavily debated. The reasons for this include, but are not limited to:

- the very low concentration of DNA with tumor-associated alterations in the blood/body fluids of earlystage cancer patients;

- the insufficient sensitivity and specificity of tests for the detection/quantification of tumor-associated alterations (especially in a diagnostic setting);

- a gap in our understanding of which factors contribute to the formation of changes which might lead to a tumor development (age-dependent methylation changes which can be detected in tumor patients and in older but otherwise healthy people alike).

In a recently published review, the prospects and challenges for liquid biopsy for the African continent with poor resources and limited access to medical infrastructures were looked at [2]. Although the statement that liquid biopsy "eliminates the need for surgical biopsies" is highly understandable, it remains unrealistic. A literature survey on the analysis of circulating tumor DNA (ctDNA) issued by the American Society of Clinical Oncology and the College of American Pathologists stated that "some ctDNA assays are clinically useful for certain types of advanced tumors" [3]. In contrast, this type of analysis does not yet hold any clinical utility for ctDNA analysis in early-stage cancer, therapy monitoring or residual disease detection. Additionally, the authors stressed the need for closing the gaps in our understanding of pre-analytical factors. We are still far away from recognizing the importance of pre-analytical influences on the outcome of laboratory tests. This was demonstrated in a paper (just to give an example) on the challenges for the implementation of 
methods for the screening for fetal aneuploidy in pregnant women with the aid of cell-free DNA (cfDNA) in which the issue of pre-analytics is not even mentioned [4].

The first meeting on Circulating Nucleic Acids in Plasma and Serum (CNAPS) that was organized 20 years ago by the founders of the liquid biopsy field Drs. Stroun and Anker, already called for a standardization of the numerous pre-analytical issues. By now, the approach of liquid biopsy is not only commercialized (as a screening method for a non-invasive prenatal detection of fetuses with numeric chromosomal aberrations like trisomy 21) but is also approved by several regulatory agencies for taking care of cancer patients (such as the detection of emerging resistance mutations against first-line $E G F R$ therapy). A recently published review lists 14 clinical trials focusing on the use of cfDNA in tumor patients, but none of them deals with pre-analytical issues [5].

A striking example for the urgent need for a standardization of sample handling and processing is the paper by Trigg et al. [6] in which 50 randomly sampled papers (all published in 2015) were reviewed. A third of them did not provide any information on the method for the plasma/ serum isolation, 19/50 did not detail the specification for the centrifugation steps to free the matrix from blood cells, and 18 of them gave no information on the cfDNA quantification method. Also, when browsing the literature for this survey, we stumbled upon some papers in which plasma was used for the analysis but was called serum and vice versa. Additionally, our knowledge about the biology of cell-free nucleic acids, their mechanisms of liberation, the composition and interaction with other molecules (like proteins, lipids and fatty acids), which may play an important role in transportation and their removal from the body, is still very rudimentary.

The aim of the paper is to review and critically summarize the data on previous attempts to set up standard operating procedures (SOPs) in the field of liquid biopsy. We will focus on papers dealing with cell-free nucleic acids and exclude work done on circulating tumor cells.

\section{Biology of cfDNA}

Cell-free nucleic acids are not only found in the circulation (i.e. plasma/serum and lymphatic fluid) but also in all examined body fluids [7]. Among them is urine [8-10], cerebrospinal fluid (CSF) [11, 12], pleural fluid including ascites [13, 14], saliva [15, 16], bronchial lavage fluid [17] and the cell-free supernatant from fine needle aspiration of thyroid nodules [18]. The ubiquitous occurrence of cell-free nucleic acids leads one to assume that these molecules might have a biological meaning. Nevertheless, there are still more questions than answers and our knowledge on this subject is very limited.

Gahan and Stroun demonstrated that newly synthesized DNA/RNA-lipoprotein complexes (termed virtosome) are released from eukaryotic cells into the environment [19]. These complexes are easily taken up and are able to modify the recipient cells. This transfer of genetic information from $\mathrm{T}$ to $\mathrm{B}$ lymphocytes was demonstrated in mice which were injected with cfDNA from human $\mathrm{T}$ cells which had previously been exposed to different viruses [20]. A few days later, these mice that were never exposed to the actual pathogen produced anti-virus-specific human antibodies. In a different set of experiments, it was shown that tumor DNA injected into mice is able to induce the development of a tumor [21]. In a report published some years ago, Gartler had demonstrated that in vitro cultivated cells are able to incorporate labeled DNA. He postulated the possibility for a "non-cellular transfer of genetic information in higher organisms" [22]. Cell-free fetal DNA was also shown to have an immune-modulating effect in vivo in pregnant mice [23], and the priming of dendritic cells by DNA from exosomes was demonstrated in a mouse model [24]. Later, Garcia-Olmo and coworkers reported that cellfree nucleic acids isolated from the plasma of colorectal cancer (CRC) patients could induce an oncogenic transformation of susceptible in vitro cultivated cells [25]. Additionally, this group also performed several in vitro and in vivo experiments which led them to conclude that cell-free nucleic acids might play a role in metastasis [26, 27]. Mittra et al. demonstrated that cell-free nucleic acids and cellfree chromatin particles can enter healthy cells, integrate into their genomes and elicit DNA double-strand breaks and apoptotic responses [28]. Because of genomic integration, the NF- $\mathrm{KB}$ pathway is activated leading to the induction of a systemic inflammation, which in turn is seen as the cause of different acute and chronic diseases. Among them is chemotherapy-induced toxicity, which is assumed to be caused by the release of a large amount of cell-free chromatin from dying cells inducing DNA damage, apoptosis and inflammation in healthy bystander cells. The administering of substances able to neutralize and/or degrade cell-free chromatin led to a decrease in inflammatory cytokines, a reduction in apoptosis and inflammation, and the prevention of prolonged neutropenia after chemotherapy treatment [29]. A stress signaling function for oxidized cfDNA was recently described [30]. A good review on the functional aspects of cfDNA was recently published by Aucamp and coworkers [31]. In addition, the size of cfDNA originating from different sources (such as 
cell-free fetal DNA or ctDNA released from tumor cells) matters and needs to be considered.

\section{Basic principles of cell-free nucleic acids: release, half-life and removal}

In the first paper describing the presence of extracellular nucleic acids in humans, 10 healthy people and 15 persons with a variety of different health issues (but no cancer patients) were analyzed [32]. Interestingly, only a pregnant woman (third trimester) demonstrated an increased amount of nucleic acids differing from all other subjects. This is in contrast to many later published papers, which show an increased quantity of cell-free plasma DNA in almost all cancer patients [33].

Even if plasma and serum are frequently the first choice to look for cell-free nucleic acids, they were also detected in other body fluids like urine $[10,34,35]$. Interestingly, DNA from urine supernatants has not only been used in patients with genitourinary cancers (such as prostate, bladder and kidney) but seems to be useful in patients with non-urological cancers as well (reviewed in Jain et al. [36]).

From the very beginning of the analysis of cell-free nucleic acids, it was an obvious assumption that DNA and RNA are released into the cellular environment by apoptosis and necrosis. These mechanisms play an important role, but an active release of nucleic acids was shown as well [37]. There are several reports demonstrating that nucleic acids are attached on the outside of cells and can be released by a mild ethylenediaminetetraacetic acid (EDTA) or trypsin treatment $[38,39]$. A recent report states that the majority of plasma cfDNA is located inside of exosomes [40]. The examination of supernatants from in vitro cultivated cells for the presence of cell-free nucleic acids showed that

- the amount of released DNA follows a tight regulation,

- the quantity of cfDNA is independent of the number of apoptotic and necrotic cells, and

- there is a correlation between the number of cells in the G1 phase and the quantity of cfDNA [31, 41, 42].

Additional evidence for an active and regulated release of cfDNA was reported by Toth et al. who described a circadian rhythm for the release of cell-free total DNA and methylated SEPTIN 9 DNA in a small group of CRC patients [43]. When they collected blood at four different times (12 pm, $6 \mathrm{am}, 12$ am and $6 \mathrm{pm}$ ), there was a modest variation for DNA in one healthy subject and one patient with adenoma, whereas the variation was larger in CRC patients with stage II-IV. The peak for SEPTIN 9 DNA was at midnight or 6 am for stage I/II patients, whereas for stage III/IV patients it was 12 am or $6 \mathrm{pm}$. Summarizing their data, they found that samples taken at midnight were always positive for cell-free SEPTIN 9 DNA but only in $78 \%$ of the samples taken at the other time points. These are interesting observations, but unfortunately the study population is too small (11 subjects in total) to draw any significant conclusions. Rasmussen and co-workers analyzed plasma and serum samples taken from healthy volunteers 3 times a day ( $8 \mathrm{am}, 12 \mathrm{am}$ and $3 \mathrm{pm}$ ) for the quantity of nucleosomes containing 5-methylcytosine (5mC) DNA or the histone modification H3K9Me3, but did not find any fluctuation [44]. When they looked for differences in these markers in serum samples obtained on different days (day 1, 8, 15, 22 and 29), the intra-individual variation was $12.7 \%$ and $11.5 \%$ for $5 \mathrm{mC}$ and $\mathrm{H} 3 \mathrm{~K} 9 \mathrm{Me} 3$, respectively. A similar observation was reported for the amount of cfDNA in urine [45]. The quantity of cfDNA from male and female healthy subjects, which was isolated over several days, demonstrated a large day-to-day variation in both sexes (the urine was collected always at the same time of the day, i.e. in the morning between $9 \mathrm{am}$ and $10 \mathrm{am})$.

Garcia-Olmo and coworkers [46] used an animal model (tumor-bearing rats injected with colon tumor cells) to demonstrate a time-dependent fluctuation of cellfree tumor DNA. They also observed a fluctuation in the amount of cell-free tumor DNA when compared to the total DNA quantity but were unable to demonstrate any relationship to tumor size. A similar fluctuation of shedding tumor cells into urine was recently reported in prostate cancer patients [8]. Gasparello et al. used several in vitro cultivated cell lines and tumor xenografts from these cell lines for the analysis of mutated cfDNA [47]. They observed that LS174T cells secret much less DNA into cell-culture supernatants than LoVo cells, but the amount of mutated DNA from LS174T xenografts was much higher than from LoVo xenografts. Additional studies of tumor tissue from xenograft mice showed that ctDNA release operates independently from housekeeping functions, which are connected to cell proliferation, tumor necrosis and vascularization. Their conclusion was that the amount of cfDNA seems to reflect a cell line-dependent property.

The published data on half-life and clearance mechanisms are summarized in Table 1.

The overarching message from this compilation is that cell-free nucleic acids demonstrate a short half-life 
Table 1: Half-life of cfDNA.

\begin{tabular}{llll}
\hline Reference & System & Nucleic acid & Detection method \\
\hline$[48]$ & Mice model & $\begin{array}{l}\text { IV injection of tritium- } \\
\text { labeled DNA }\end{array}$ & $\begin{array}{l}\text { TCA precipitation and } \\
\text { measurement of specific } \\
\text { radioactivity }\end{array}$ \\
{$[49]$} & Mice model & $\begin{array}{l}\text { IV injection of }{ }^{125} \text {-labelled } \\
\text { mononucleosomes }\end{array}$ & $\begin{array}{l}\text { TCA precipitation and } \\
\text { measurement of specific } \\
\text { radioactivity }\end{array}$
\end{tabular}

[50] Mice model IV injection of tritiumlabeled genomic DNA and poly I-poly C preparations

[51]

$\begin{array}{ll}\text { Mice model } & \text { IV injection of dsDNA } \\ & \text { and ssDNA of purified } \\ & \text { calf thymus DNA, }{ }^{125} \text { - } \\ & \text { labeled, large fragments } \\ & (1-2 \mathrm{~kb})+\text { small } \\ \text { fragments }(75-100 \mathrm{bp}) \\ \text { oligonucleotides }(5-15 \\ \text { bases })\end{array}$

[52] $\begin{array}{ll}\text { Mice model } & \text { Injection of a soluble form } \\ & \text { of chromatin into retro- } \\ & \text { orbital sinus, }\left.\right|^{125} \text {-labeled }\end{array}$

$\begin{array}{lll}\begin{array}{l}\text { Pregnant } \\ \text { women }\end{array} & \begin{array}{l}\text { Male fetal DNA, SRY } \\ \text { sequence }\end{array} & \text { q-PCR } \\ & \end{array}$

$\begin{array}{ll}\text { Mice } & \text { Injection of irradiated } \\ \text { model and } & \text { Raji cells or 32P-labeled } \\ \text { pregnant } & \lambda \text {-phage DNA into mice }\end{array}$

women,

cancer

patients

Patients

with NPC

Quantification of EBV

DNA in patients receiving radiotherapy

Patients with NPC

Patients with kidney transplants

q-PCR

Male-specific DNA

DNA in patients who are
Precipitation with specific antibodies or TCA

TCA precipitation

TCA precipitation

PCR for detection of different targets ( $\lambda$ DNA, Raji cells), $D Y Z 1$ gene (pregnant women), $K$-ras mutant

q-PCR

$q-P C R$

-PCR

\section{Remarks}

More than $99 \%$ of the total radioactivity was removed from the circulation in the first $30 \mathrm{~min}$ (rapid phase) and was excreted through the kidney Rapid removal of mononucleosomes from the circulation when up to $11 \mu \mathrm{g}$ DNA was injected; with increasing doses of injected mononucleosomes, slopes of removal curves decreased; the liver was the major organ for removal ( $71 \%-84 \%$ in $10 \mathrm{~min})$

Intact and denatured DNA is very rapidly cleared (first $3 \mathrm{~min}$ after injection), then elimination rate gradually decreases; at 60 min only $10 \%$ DNA detectable, serum nucleases not important for DNA removal, liver and spleen show fast and high uptake of administered DNA

Removal of all DNA preparation followed an exponential curve (two components), $1^{\text {st }}$ component $=$ organ uptake, $2^{\text {nd }}$ component $=$ excretion of breakdown products (same slope for all DNA preparations), initial clearance of large ssDNA was significantly faster than dsDNA; max persistence in the circulation was $20 \mathrm{~min}$ (ssDNA) and $40 \mathrm{~min}$ (dsDNA), ssDNA is mainly removed by the liver, dsDNA + oligonucleotides are mainly removed by soft tissue

Liver uptake is the most important factor for histone clearance, Kupffer cells + macrophages specifically needed, pretreatment of mice with DNA strongly inhibits chromatin clearance (same receptors responsible for chromatin + DNA clearance)

Mean half-life for cell-free fetal DNA is $16 \mathrm{~min}$ (4-30 min), DNA removal consists of two phases (one initial rapid phase + a slower $2^{\text {nd }}$ phase) Majority of injected DNA is recycled, only $3 \%$ is excreted into urine over 3 days, Raji-specific DNA is detectable in urine as well, $77 \mathrm{bp}$ amplicons of $Y$-chromosome-specific sequences found in urine of pregnant women as well as mutated $K$-rasamplified DNA from pancreas of carcinoma patients Median half-life of plasma EBV DNA was found to be 3.8 days, this value seems to reflect the cell death rather than the actual clearance of EBV DNA from plasma

Median half-life of cell-free EBV DNA in NPC patients was $139 \mathrm{~min}$

Cell-free transplant-derived kidney DNA was found in urine and plasma, no male-specific DNA was found in urine by day 7 after transplantation, malespecific kidney-derived cell-free DNA disappeared much faster from plasma than from urine (no detailed data provided)

In the majority of patients (16/18), the prehemodialysis DNA level was reached $30 \mathrm{~min}$ after end of the procedure 
Table 1 (continued)

\begin{tabular}{|c|c|c|c|c|}
\hline Reference & System & Nucleic acid & Detection method & Remarks \\
\hline$[59]^{\mathrm{b}}$ & $\begin{array}{l}\text { In vitro } \\
\text { stability } \\
\text { experiment }\end{array}$ & $\begin{array}{l}\text { Quantification of Candida } \\
\text { albicans DNA }\end{array}$ & $\mathrm{q}-\mathrm{PCR}$ & $\begin{array}{l}\text { Incubation of purified (QIAamp DNA Blood Mini Kit) } \\
\text { cell-free Candida DNA in human or rabbit plasma } \\
\text { for up to } 3 \text { days at RT demonstrated no change in } \\
\text { DNA concentration }\end{array}$ \\
\hline$[60]^{c}$ & $\begin{array}{l}\text { Healthy } \\
\text { subjects } \\
\text { and cancer } \\
\text { patients }\end{array}$ & $\begin{array}{l}\text { Quantification of total } \\
\text { cell-free DNA }\end{array}$ & $\begin{array}{l}\text { Quantification by Hoechst } \\
33258 \text { dye }\end{array}$ & $\begin{array}{l}\text { In healthy people, different levels of DNase } \\
\text { activity was found in combination with low levels } \\
\text { of cfDNA (range } 0-66 \mathrm{ng} / \mathrm{mL} \text { ), in } 18 \text { cancer } \\
\text { patients no DNase activity was demonstrated } \\
\text { but an increased amount of cell-free DNA (range } \\
0->1000 \mathrm{ng} / \mathrm{mL} \text { ) }\end{array}$ \\
\hline [61] & $\begin{array}{l}\text { Patients } \\
\text { with } \\
\text { colorectal } \\
\text { cancer }\end{array}$ & $\begin{array}{l}\text { Quantification of total } \\
\text { and mutant cell-free } \\
\text { DNA before and after } \\
\text { treatment }\end{array}$ & $\begin{array}{l}\text { q-PCR (total DNA), BEAMing } \\
\text { (tumor-associated DNA) }\end{array}$ & $\begin{array}{l}\text { Kinetic analysis of the quantity of ctDNA in one (!) } \\
\text { patient showed a half-life of } 114 \text { min after surgery }\end{array}$ \\
\hline [62] & $\begin{array}{l}\text { Pregnant } \\
\text { women }\end{array}$ & $\begin{array}{l}\text { Quantification of cell-free } \\
\text { fetal and maternal DNA }\end{array}$ & Paired-end sequencing & $\begin{array}{l}\text { Two phases of fetal DNA clearance (fast }=0-2 \mathrm{~h} \text { and } \\
\text { slow }=6-18 \mathrm{~h} \text { ), fetal DNA half-life of the phases } \\
\text { was } 1 \mathrm{~h} \text { and } 13 \mathrm{~h} \text {, respectively, clearance via } \\
\text { kidney up to } 19 \% \text { of fetal DNA only }\end{array}$ \\
\hline$[63]^{\mathrm{d}}$ & $\begin{array}{l}\text { In vitro } \\
\text { system }\end{array}$ & $\begin{array}{l}\text { Naked DNA and DNA- } \\
\text { protein complexes were } \\
\text { spiked into serum, saliva } \\
\text { or urine }\end{array}$ & $\begin{array}{l}\text { Amplification of a panel of } \\
\text { short tandem repeat loci }\end{array}$ & $\begin{array}{l}\text { Half-lives of DNA with/without protein in serum } \\
158 \mathrm{~min} / 31 \mathrm{~min} \text { at } 37^{\circ} \mathrm{C} \text {, half-lives of DNA with } \\
\text { protein in saliva }=176 \mathrm{~min} \text { at } 37^{\circ} \mathrm{C} \text { and } 252 \mathrm{~min} \\
\text { at RT, half-lives of DNA in urine (with and without } \\
\text { protein) were too short to be detectable }\end{array}$ \\
\hline [64] & $\begin{array}{l}\text { Rabbit } \\
\text { model }\end{array}$ & $\begin{array}{l}\text { Injection of tumor cells } \\
(\mathrm{VX} 2) \text { into the animal }\end{array}$ & $\begin{array}{l}\text { Quantification of total and } \\
\text { tumor-associated }(\mathrm{VX} 2) \\
\text { cell-free DNA by q-PCR }\end{array}$ & $\begin{array}{l}\text { Surgical resection of the tumor ctDNA levels } \\
\text { decreased with a half-life of } 23-52 \mathrm{~min}\end{array}$ \\
\hline [65] & Dog model & $\begin{array}{l}\text { Quantification of total } \\
\text { cell-free DNA before and } \\
\text { after surgical procedures } \\
\text { ( } 6 \mathrm{~h} \text { to } 3 \text { days) }\end{array}$ & Qubit dsDNA HS Assay Kit & $\begin{array}{l}\text { Half-life of cell-free DNA was determined to be } \\
5.6 \mathrm{~h}\end{array}$ \\
\hline
\end{tabular}

aThe authors performed an additional experiment in which they collected blood in "plain tubes" before cesarean section and at $2 \mathrm{~h}$ after delivery, processed these samples immediately after blood draw (centrifugation) and incubated the supernatant for $2 \mathrm{~h}$ at $37^{\circ} \mathrm{C}$ (only the pre-cesarean samples). In 3/10 samples, there was almost no change in fetal DNA concentration while the other seven samples showed values of $31 \%-74 \%$ of pre-cesarean values. In contrast, in 9/10 samples taken $2 \mathrm{~h}$ after cesarean section, no cell-free fetal DNA was detectable. As the authors used the word "plasma", it is not clear whether the blood was sampled in EDTA tubes. In this case, their conclusion "that plasma nucleases play only a partial role in the removal of circulating fetal DNA in most subjects" might not be correct as the EDTA inhibits nuclease action. 'I is not clear why purified Candida albicans DNA behaves differently when compared with DNA from other organisms demonstrating a much higher stability in plasma. 'In other reports, it was shown that the majority of cell-free nucleic acids is taken up by the liver and the importance of DNase activity in the removal is not clear, especially as DNA released in complexes with proteins, lipids or other molecules might be protected from degradation. In addition, Koizumi et al. detected no DNase II activity in serum but in urine (Expt Anim 1995). ${ }^{\mathrm{d}}$ This report is in contrast to other papers in which the presence of cell-free nucleic acids in urine has successfully been described. A possible explanation for this discrepancy is that the rather large PCR products chosen for amplification (only 2/19 amplified STR loci generate an amplicon shorter than $100 \mathrm{bp}$ ) are suboptimal for total cfDNA quantification. cfDNA, cell-free DNA; dsDNA double-stranded DNA; EBV, Epstein-Barr virus; NPC, nasopharyngeal carcinoma; PCR, polymerase chain reaction; q-PCR, quantitative PCR; RT, room temperature; ssDNA, single-stranded DNA; TCA, trichloroacetic acid.

only. There seem to be several mechanisms involved in their clearance (liver uptake, removal through the kidney, degradation by nucleic acid degrading enzymes), but there are still open questions (just to name a few of them) as follows:

- Are the clearance mechanisms the same for all kinds of different forms of cfDNA?
- Does the half-life of cell-free nucleic acids in diseased patients differ from the ones in healthy people?

- Are there any differences in the half-life of cell-free nucleic acids in different body fluids and what are the clearance mechanisms in these fluids?

- A deeper understanding of the mechanisms involved in the liberation of extracellular nucleic acids into the 
environment (including but not limited to circadian rhythms),

- Composition and physical, chemical and biological properties of particles associated with cell-free nucleic acids,

- Half-life of these different particles, which contain cell-free nucleic acids and mechanisms of their clearance.

\section{How to choose an optimal control population}

In many studies aiming to establish genetic marker/s useful in a diagnostic setting, healthy people (not too seldom young blood donors) are used as controls. This might not be a good idea, as it is important to discriminate cancer patients not from healthy people but specifically from patients with benign diseases affecting the same organ. Apart from age and different environmental influences (factors that are taken into consideration in some studies), chronic nonmalignant diseases have an effect on the genetic makeup of cells which should not be underestimated. This applies in particular to inflammatory processes, which are associated with genetic and epigenetic alterations playing a role in the development of a tumor. The presence of chromosomal translocations frequently found in lymphomas had been described in healthy people already some years ago [66-68]. In addition, an allelic imbalance and an overexpression of TP53 and CCND1 (CYCLIN D1 protein) was found in normal lung tissue from a patient with lung cancer [69]. Mutations of the TP53 and KRAS genes were also detected in plasma samples prospectively collected in a large group of healthy subjects [70]. Upon follow-up examinations, 16/33 people harboring a mutation in one of the two genes developed a tumor approximately 1.5 years after blood collection. This demonstrates that about $50 \%$ of this group was not healthy when they were included in the study. The analysis of cellfree plasma DNA also detected TP53 mutations in $11.4 \%$ of the non-cancer controls [71], and in 7.4\% of healthy subjects analyzed for the presence of KRAS mutations [72]. In peritoneal fluids of women without cancer, low frequency of TP53 gene mutations and an age-dependent increase were found [73]. Whole-exome sequence analysis of 12,380 people without a malignant disease showed a clonal hematopoiesis with somatic mutations in 3111 of them and a strong correlation with age [74]. It was demonstrated that people with clonal hematopoiesis were more likely to receive a diagnosis of hematologic cancer, but so far there is no method to differentiate between this group and people who live with this alteration and not being diagnosed with a tumor (although this might change in long-term follow-up trials). Many mutations found in primary tumor samples were also detected in genomic DNA from white blood cells (WBCs) as background mutations (germline polymorphisms and mutations with low allele frequency $[\mathrm{AF}]$, i.e. $<10 \%$ ), which will make it harder to differentiate between people with an early stage of cancer and healthy people $[8,75]$. In addition, there are several papers in which genetic alterations frequently found in tumor cells were detected in normal tissues (apart from WBC) [76-78].

It is expected that an increase in the analytical sensitivity of methods for the detection of low-level genetic alterations not only in tissue but in body liquids as well will lead to an increasing number of reports demonstrating the presence of tumor-associated alterations (genetic and epigenetic) in healthy subjects. Therefore, the choice of controls (such as the appropriate use of spike-in controls or other reference material) and the determination of cut-off values are becoming even more important.

\section{Preparation of cell-free body fluids}

According to the data collected in Table 2, our own experience, and a survey conducted at the CNAPS IX meeting, this step is probably the first one on which to agree on a standard operational procedure. In order to remove not only intact cells but also debris and other large particles, it is absolutely necessary to perform two centrifugation steps. The second centrifugation can be performed after thawing plasma samples without any loss of information [81], and even a third centrifugation step does not introduce any bias. Alternatively, a filtration step can be included which has been shown to work equally well but takes more time and needs a filtration device [79].

Recommendation: In order to make sure that plasma samples are cell-free, they should be re-centrifuged at high speed before DNA extraction. This holds especially for samples which are collected and processed in several locations and are shipped (frozen) for analysis.

\section{Comparison of blood-drawing tubes with different anticoagulants}

In the early days of cfDNA analysis, a few papers were published comparing different anticoagulants and it was shown that EDTA and citrate performed equally well (Table 3). 
Table 2: Methods for the generation of cell-free plasma.

\begin{tabular}{|c|c|c|c|c|}
\hline Reference & Samples & Centrifugation method & Detection method & Remarks \\
\hline [79] & $\begin{array}{l}\text { EDTA blood, pregnant } \\
\text { women }\end{array}$ & $\begin{array}{l}\text { Medium speed }(1600 \mathrm{~g}) \text { alone or } \\
\text { in combination with high speed } \\
(16,000 \mathrm{~g}) \text { or filtration, low speed } \\
(800 \mathrm{~g}) \text { alone or in combination } \\
\text { with high speed }(16,000 \mathrm{~g}) \text { or } \\
\text { filtration, Percoll gradient alone or } \\
\text { in combination with high speed or } \\
\text { filtration }\end{array}$ & $\begin{array}{l}\text { Quantification of total and } \\
\text { fetal DNA conc. (q-PCR) }\end{array}$ & $\begin{array}{l}\text { Incomplete removal of WBC } \\
\text { leads to high total DNA } \\
\text { conc. but does not affect } \\
\text { fetal DNA, double spin (low/ } \\
\text { medium speed + high speed) } \\
\text { or spinning + filtration gives } \\
\text { best results }\end{array}$ \\
\hline [80] & $\begin{array}{l}\text { EDTA blood, sex- } \\
\text { mismatched bone } \\
\text { marrow transplantation } \\
\text { patients }\end{array}$ & $400 \mathrm{~g}$ up to $16,000 \mathrm{~g}$ for $10 \mathrm{~min}$ & $\begin{array}{l}\text { Quantification of total DNA } \\
\text { conc. (q-PCR) }\end{array}$ & $\begin{array}{l}\text { No change of total cell-free } \\
\text { DNA conc. in all samples }\end{array}$ \\
\hline [81] & $\begin{array}{l}\text { EDTA blood ( } 7 \mathrm{~mL} \text { and } \\
10 \mathrm{~mL} \text { tubes), pregnant } \\
\text { women }\end{array}$ & $\begin{array}{l}800 g \text { or } 800 g+16,000 g(7 \mathrm{~mL} \text { tubes }) \\
800 g \text { or } 800 g+16,000 g(10 \mathrm{~mL} \text { tube })\end{array}$ & $\begin{array}{l}\text { Quantification of total DNA } \\
\text { conc. (q-PCR) }\end{array}$ & $\begin{array}{l}\text { Low-speed spinning removes } \\
\text { WBC in } 7 \mathrm{~mL} \text { tubes but not } \\
\text { in } 10 \mathrm{~mL} \text { tubes (double spin } \\
\text { necessary), } 2^{\text {nd }} \text { spin can be } \\
\text { performed after thawing of } \\
\text { plasma sample (!) }\end{array}$ \\
\hline [82] & $\begin{array}{l}\text { EDTA blood, banked } \\
\text { and prospectively } \\
\text { collected samples from } \\
\text { healthy people and } \\
\text { cancer patients }\end{array}$ & $\begin{array}{l}1600 \mathrm{~g} 5 \mathrm{~min} \text { (banked plasma) } \\
2 \times 1600 \mathrm{~g} 10 \mathrm{~min} \text { (prospectively } \\
\text { collected plasma) }\end{array}$ & $\begin{array}{l}\text { Quantification of total DNA } \\
\text { conc. (q-PCR) }\end{array}$ & $\begin{array}{l}\text { Prospectively collected } \\
\text { samples had lower DNA } \\
\text { concentrations than banked } \\
\text { samples, no difference in } \\
\text { cfDNA conc. between cancer } \\
\text { patients and controls }\end{array}$ \\
\hline [83] & $\begin{array}{l}\text { EDTA, healthy female } \\
\text { donors }\end{array}$ & $\begin{array}{l}2 \times 2000 \mathrm{rpm} \text { for } 10 \mathrm{~min}, 2000 \mathrm{rpm} \\
\text { for } 10 \mathrm{~min}+13,500 \mathrm{rpm} \text { for } 5 \mathrm{~min}\end{array}$ & PCR & $\begin{array}{l}\text { Amplification products } \\
\text { of }>300 \text { bp are not seen } \\
\text { after high-speed spinning, } \\
\text { this step (high-speed } \\
\text { centrifugation) can be } \\
\text { performed after thawing, i.e. } \\
\text { before DNA isolation }\end{array}$ \\
\hline [84] & $\begin{array}{l}\text { EDTA, healthy female } \\
\text { donors }\end{array}$ & $\begin{array}{l}2 \times 1000 \mathrm{~g} \text { for } 10 \mathrm{~min}, 1000 \mathrm{~g} \text { for } \\
10 \mathrm{~min}+1000 \mathrm{~g}, 2000 \mathrm{~g} \text { or } 10,000 \mathrm{~g} \\
\text { for } 10 \mathrm{~min} \text { each }\end{array}$ & $\begin{array}{l}\text { Quantification of total DNA } \\
\text { conc. (q-PCR) }\end{array}$ & $\begin{array}{l}\text { CfDNA yield was the same } \\
\text { for all spinning protocols, } \\
\text { two-step spinning with high } \\
\text { speed }(10,000 \mathrm{~g}) \text { reduced } \\
\text { the number of quantifiable } \\
\text { miRNAs from } 195 \text { to } 138\end{array}$ \\
\hline [85] & EDTA, NSCLC patients & $1 \times$ vs. $2 \times$ spin at $2000 g$ for $10 \mathrm{~min}$ & $\begin{array}{l}\text { Quantification of total DNA } \\
\text { conc. (q-PCR) }\end{array}$ & $\begin{array}{l}\text { Spinning protocol }(1 \times v \text { s. } \\
2 \times \text { centrifugation }) \text { had no } \\
\text { influence on cfDNA yield when } \\
\text { samples were processed } 2 \mathrm{~h} \\
\text { after blood draw, at } 3 \text { day } \\
\text { processing double spinning } \\
\text { reduced cfDNA }\end{array}$ \\
\hline [86] & $\begin{array}{l}\text { EDTA, healthy people } \\
\text { and cancer patients }\end{array}$ & $\begin{array}{l}1 \times 800 \mathrm{~g} \text { for } 10 \mathrm{~min} \\
800 \mathrm{~g} \text { for } 10 \mathrm{~min}+11,000 \mathrm{~g} 1 \mathrm{~min} \\
800 \mathrm{~g} \text { for } 10 \mathrm{~min}+11,000 \mathrm{~g} 1 \mathrm{~min} \\
\text { (after thawing) } \\
380 \mathrm{~g} \text { for } 20 \mathrm{~min}+20,000 \mathrm{~g} 10 \mathrm{~min} \\
380 \mathrm{~g} \text { for } 20 \mathrm{~min}+20,000 \mathrm{~g} 10 \mathrm{~min} \\
\text { (after thawing) }\end{array}$ & $\begin{array}{l}\text { NanoDrop } \\
\text { spectrophotometry, ddPCR }\end{array}$ & $\begin{array}{l}\text { First protocol gave the } \\
\text { highest yield of cfDNA ( } 72 \\
\text { copies } / \mu \mathrm{L} \text { ), all other methods } \\
\text { were comparable (range } \\
28-40 \text { copies } / \mu \mathrm{L})\end{array}$ \\
\hline [87] & EDTA, cancer patients & $\begin{array}{l}820 \mathrm{~g} \text { for } 10 \mathrm{~min}+14,000 \mathrm{~g} \text { for } 10 \mathrm{~min} \\
1600 \mathrm{~g} \text { for } 10 \mathrm{~min}+14,000 \mathrm{~g} \text { for } \\
10 \mathrm{~min} \\
1600 \mathrm{~g} \text { for } 10 \mathrm{~min}+3000 \mathrm{~g} \text { for } 10 \mathrm{~min}\end{array}$ & $\begin{array}{l}\text { Total DNA quantification } \\
\text { (dPCR) and mutant } \\
\text { detection (targeted } \\
\text { amplicon sequencing) }\end{array}$ & $\begin{array}{l}\text { No difference for all spinning } \\
\text { protocols regarding total } \\
\text { amount of cell-free DNA and } \\
\text { mutant allele fraction }\end{array}$ \\
\hline
\end{tabular}


Table 2 (continued)

\begin{tabular}{|c|c|c|c|c|}
\hline Reference & Samples & Centrifugation method & Detection method & Remarks \\
\hline [88] & $\begin{array}{l}\text { EDTA, healthy people } \\
\text { and cancer patients } \\
\text { with mutated KRAS }\end{array}$ & $\begin{array}{l}1 \times 400 \mathrm{~g} \text { for } 10 \mathrm{~min} \\
400 \mathrm{~g} \text { for } 10 \mathrm{~min}+\max \text { speed for } \\
1 \mathrm{~min} \\
120 \mathrm{~g} \text { for } 20 \mathrm{~min}+360 \mathrm{~g} \text { for } \\
20 \mathrm{~min}+360 \mathrm{~g} \text { for } 5 \mathrm{~min} \\
1600 \mathrm{~g} \text { for } 10 \mathrm{~min}+6000 \mathrm{~g} \text { for } 10 \mathrm{~min} \\
1900 \mathrm{~g} \text { for } 10 \mathrm{~min}+16,000 \mathrm{~g} \text { for } \\
10 \mathrm{~min}\left(4^{\circ} \mathrm{C} \text { or RT) }\right.\end{array}$ & $\begin{array}{l}\text { ddPCR } K R A S \text { screening } \\
\text { multiplex kit for total and } \\
\text { mutant DNA conc. }\end{array}$ & $\begin{array}{l}\text { For biobanking without } \\
\text { predefined downstream } \\
\text { application, the first protocol } \\
\text { is recommended; for the } \\
\text { analysis of cfDNA, the last } \\
\text { protocol (high speed at } 4^{\circ} \mathrm{C} \\
\text { or RT) are optimal }\end{array}$ \\
\hline
\end{tabular}

Anker et al. [89]: even high-speed centrifugation (45,000 rpm) does not seem to harm cells (liberation of their nucleic acids) but brake should be reduced! cfDNA, cell-free DNA; ddPCR, droplet digital PCR; dPCR, digital PCR; EDTA, ethylenediaminetetraacetic acid; miRNAs, micro RNAs; NSCLC, non-small cell lung carcinoma; q-PCR, quantitative PCR; RT, room temperature; WBC, white blood cell.

Table 3: Comparison of different anticoagulants.

\begin{tabular}{|c|c|c|c|c|}
\hline Reference & Tube/anticoagulant & Plasma samples & Detection method & Remarks \\
\hline [90] & EDTA, citrate & Healthy volunteers & $\mathrm{q}-\mathrm{PCR}$ & $\begin{array}{l}\text { cfDNA quantity was compared to serum, } \\
\text { no data on comparison between EDTA } \\
\text { and citrate }\end{array}$ \\
\hline [91] & $\begin{array}{l}\text { EDTA, heparin, } \\
\text { citrate }\end{array}$ & Healthy volunteers & $\mathrm{q}-\mathrm{PCR}$ & $\begin{array}{l}\text { No difference in plasma cfDNA conc. in } \\
\text { all tubes when stored for up to } 6 \mathrm{~h} \text {, at } \\
24 \mathrm{~h} \text { cfDNA quantity higher in all tubes, } \\
\text { but smallest increase in EDTA tubes }\end{array}$ \\
\hline [92] & $\begin{array}{l}\text { EDTA, plain tubes } \\
\text { (serum) }\end{array}$ & Pregnant women & $\begin{array}{l}\text { q-PCR for quantification of fetal } \\
\text { DNA (DYS-14) }\end{array}$ & $\begin{array}{l}\text { DNase activity was much higher in } \\
\text { serum than in EDTA tubes, adding EDTA } \\
\text { to serum samples lead to inhibition of } \\
\text { DNase activity, serum storage at } 37^{\circ} \mathrm{C} \\
\text { lead to strong decrease in cell-free fetal } \\
\text { DNA, much less in EDTA tubes }\end{array}$ \\
\hline [93] & EDTA, citrate & $\begin{array}{l}\text { Healthy volunteers and } \\
\text { cancer patients }\end{array}$ & $\begin{array}{l}\text { Fluorometric quantification (total } \\
\text { cfDNA), mutation detection with } \\
\text { mutation-biased PCR and quench } \\
\text { probe system }\end{array}$ & $\begin{array}{l}\text { Stabilization of cfDNA after RT storage } \\
\text { for } 1 \text { or } 3 \text { days was somewhat better in } \\
\text { citrate than EDTA }\end{array}$ \\
\hline
\end{tabular}

cfDNA, cell-free DNA; EDTA, ethylenediaminetetraacetic acid; q-PCR, quantitative PCR; RT, room temperature.

Most research groups advice against the use of heparin as it is known to inhibit DNA polymerase and might lead to negative polymerase chain reaction (PCR) results. It did not take a long time to demonstrate that a delayed processing of blood-drawing tubes (EDTA, citrate, heparin, plain tubes for serum extraction) has a negative effect on cfDNA (such as a reduced detection rate for mutant sequences). Very soon, several companies made an effort to develop tubes that stabilize blood samples (see Table 4). While Streck Inc. (Omaha, NE, USA) was the first company to market a blood collection tube specifically designed to prevent lysis of nucleated blood cells after prolonged storage, some other companies like Qiagen and Roche followed. The basic principle of all these tubes is to stabilize WBCs and to prevent the "contamination" of cfDNA with genomic DNA. When DNA and blood samples were treated with the reagent used for cell stabilization (contained in blood collection tubes [BCTs]) for up to 2 weeks, there was no effect seen on amplification by PCR whereas formaldehyde or glutaraldehyde led to a significant decrease in DNA amplification [120].

From the data compiled in Tables 3 (comparing EDTAand citrate-containing tubes) and 4, it can be concluded that - EDTA or citrate perform equally well when samples are processed within a reasonable time after blood draw (4 to max. $6 \mathrm{~h}$ ) and storage at $4^{\circ} \mathrm{C}$ to ambient temperature $\left(<30^{\circ} \mathrm{C}\right)$, and

- The use of one of the blood-stabilizing tubes is highly advisable when samples need to be stored/shipped before processing. 


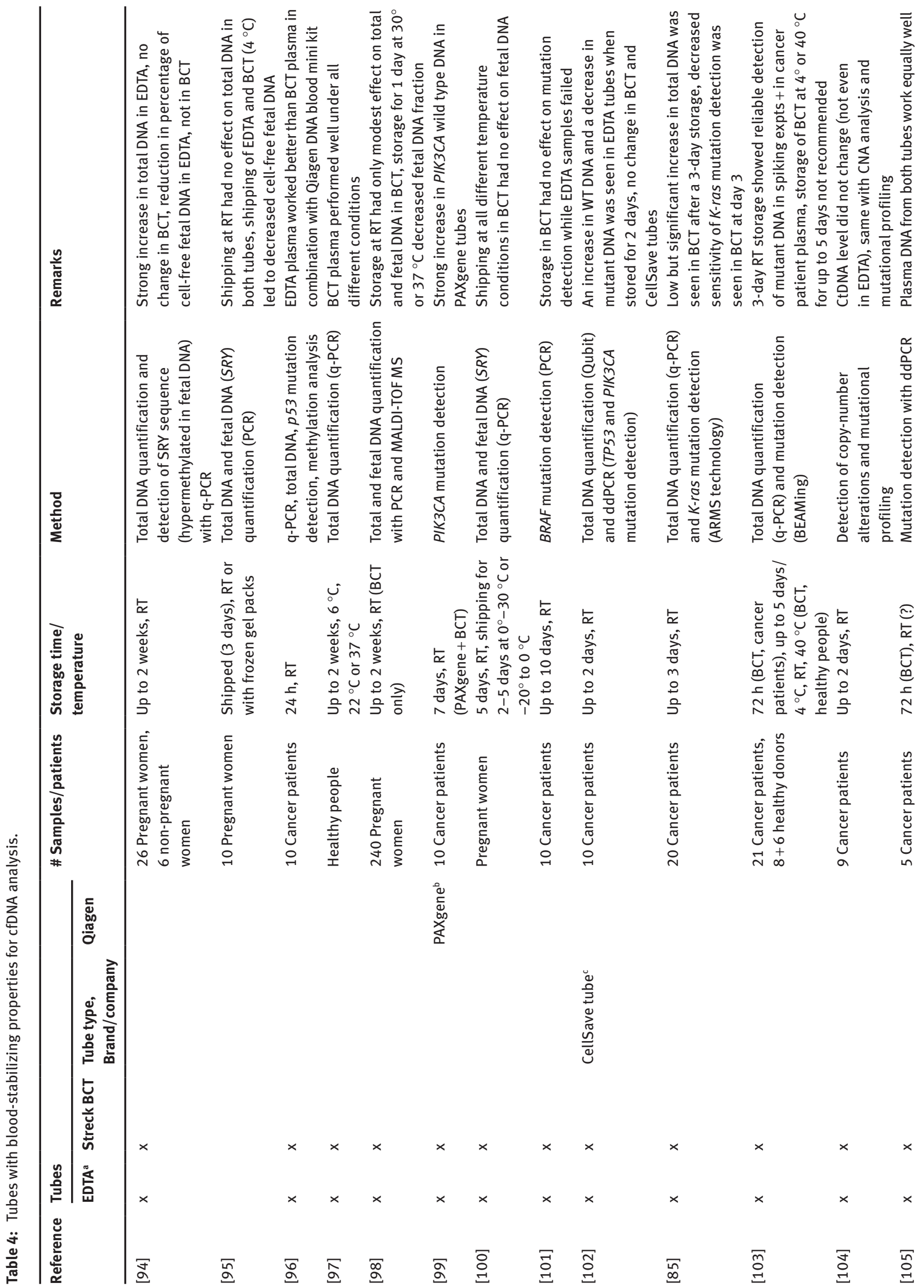




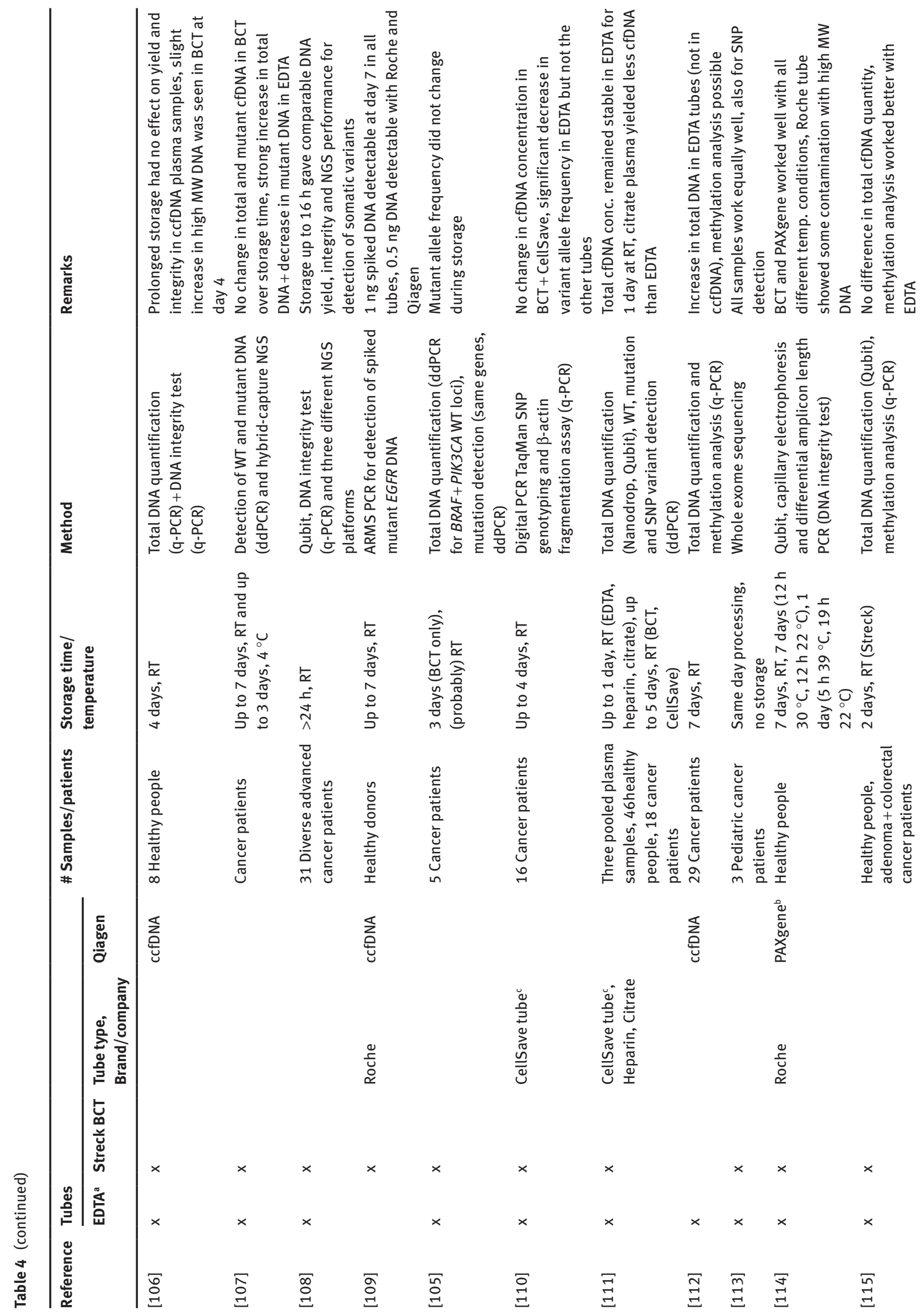




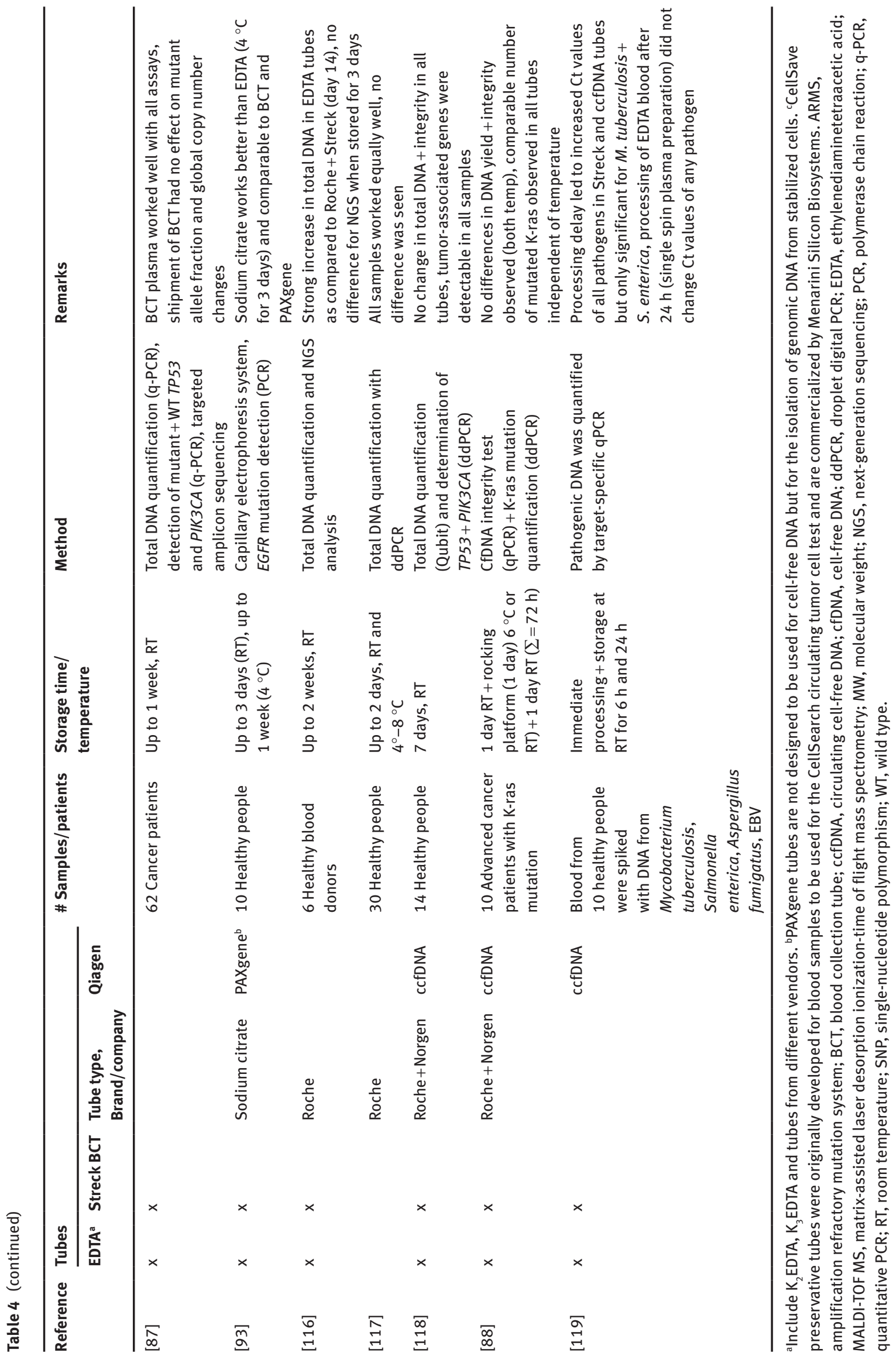




\section{What happens when processing of blood or biological fluids is delayed?}

The data compiled in Table 5 demonstrate convincingly that blood samples drawn into EDTA tubes can be stored at room temperature (RT) for a few hours without losing any information when analyzed for tumor-associated alterations. As mentioned before, cfDNA can be isolated from different body fluids like urine, CSF, saliva, pleural effusion fluids and bronchial washings [8, 132, 133]. Unfortunately, there are almost no data on how to handle these fluids in a way to optimize the isolation and characterization of extracellular nucleic acids.

In a "seven at one blow" approach, Sorber and colleagues tried to analyze the effect of a variety of different pre-analytical factors on the sensitivity of a test for the detection of EGFR mutations in the plasma of lung cancer patients [88]. One of their conclusions reads that "A longer transit time was associated with a lower amount of plasma" in combination with a one-step low-speed centrifugation protocol for plasma processing. As it was not stated in the paper how and where (outside the lab?) the tubes were stored before processing, it is not possible to comprehend this result. Additionally, it is stated that "In conclusion, transit time had a significant impact on plasma generation and the occurrence of hemolysis. However, this effect on plasma generation could be negated by using a two-step, high-speed centrifugation protocol.” For the reader, it is not clear why or how a two-step high-speed centrifugation for the plasma preparation might prevent hemolysis of the sample.

Recently, a multidisciplinay working group of specialists from different fields from Canada published a paper with recommendations to improve EGFR T790M testing for tissue and cfDNA (liquid biopsy). One statement is considered critical from our point of view, i.e. the proposition to isolate the plasma from EDTA tubes within 6 to $48 \mathrm{~h}$ after blood draw [134]. It has been demonstrated in several papers that storage of EDTA blood for more than $24 \mathrm{~h}$ (independent of the storage temperature) led to increase in DNA caused by lysis of blood cells and should be avoided by all means. If the number of mutant DNA molecules is high, this might not have an influence on the test result. In samples with a low mutant allele fraction, the increase in DNA from healthy cells might mask the detection of mutant molecules due to an increased noise. We therefore recommend to use EDTA tubes only if the plasma can be prepared within $6 \mathrm{~h}$ after blood draw. Otherwise, the application of cfDNA stabilization tubes is indicated.

\section{Factors which can impact the quantity/quality of cfDNA}

Companies like Sarstedt and Sartorius sell blood collection tubes without a vacuum, which needs to be generated manually by the phlebotomist. In contrast, many other producers developed blood collection tubes with a vacuum. So far, there are no data or a head-to-head comparison on the influence these different tubes might have on cfDNA. Other questions for which we do not have an answer yet include the following:

- Does it make a difference whether patients are fasting vs. eating?

- Does the position during blood draw (sitting vs. lying) make a difference? (It is known that the change of position from supine to sitting or vice versa has an effect on some laboratory parameters [135], but so far we do not know whether this is true for cell-free nucleic acids as well.)

- Does tourniquet stasis have an influence on the quantity/quality of cell-free nucleic acids (there is only one report which analyzed the amount of nucleosomes harboring either methylated DNA or a histone modification after blood draw with/without stasis and no difference was detected [44])?

- Does the needle size used for blood drawing (apart from being big enough to prevent hemolysis) have an effect? The recently introduced 25-gauge BD Vacutainer ${ }^{\circledR}$ UltraTouch ${ }^{\mathrm{TM}}$ needles have a diameter somewhat larger than the 23-gauge needle and perform equally well in terms of (not) causing hemolysis [136]. As these needles just entered the market, they have not yet been tested for cfDNA applications.

Other factors which might have an impact on liquid biopsy results are age, gender, ethnicity, body mass index, organ health, smoking, physical activity, diet, glucose levels, oxidative stress, medication status, infections, menstruation and pregnancy.

\section{Long-term storage of cell-free matrices and freeze-thaw cycles}

The results compiled in Table 6 give an unclear image and do not allow a firm data-based conclusion for an optimal storage method. The decay rates, which were determined in these papers, are highly variable and there is no trend (not to mention congruence) at all. We assume that the main 
Table 5: Influence of delayed blood processing on cfDNA.

\begin{tabular}{|c|c|c|c|c|c|c|}
\hline Ref & Tube & Storage time & $\begin{array}{l}\text { Storage } \\
\text { temperature }\end{array}$ & Samples & Method & Remarks \\
\hline [80] & EDTA & Up to $6 \mathrm{~h}$ & RT & $\begin{array}{l}\text { Healthy } \\
\text { people }\end{array}$ & $\begin{array}{l}\mathrm{q}-\mathrm{PCR} \text { for total DNA } \\
\text { conc. }\end{array}$ & $\begin{array}{l}\text { No difference in total DNA quantity when } \\
\text { stored for } 6 \mathrm{~h}\end{array}$ \\
\hline [121] & EDTA & Up to $24 \mathrm{~h}$ & $\begin{array}{l}4{ }^{\circ} \mathrm{C}(8+24 \mathrm{~h}) \\
\text { and RT (up to } 8 \mathrm{~h})\end{array}$ & $\begin{array}{l}\text { Healthy } \\
\text { people }\end{array}$ & $\mathrm{q}-\mathrm{PCR}$ & $\begin{array}{l}\text { Almost no change in cfDNA conc. in all } \\
\text { samples, strong increase in serum tubes } \\
\text { past } 2 \mathrm{~h} \text { at RT }\end{array}$ \\
\hline [122] & EDTA & $15 \mathrm{~min}-24 \mathrm{~h}$ & RT & $\begin{array}{l}\text { Pregnant } \\
\text { women }\end{array}$ & $\begin{array}{l}q-P C R \text { for total and } \\
\text { fetal DNA conc. }\end{array}$ & $\begin{array}{l}\text { Strong increase in total DNA conc. after } 6 \mathrm{~h} \text {, } \\
\text { no change in fetal DNA conc. up to } 1 \mathrm{day}\end{array}$ \\
\hline [123] & EDTA & $6 \mathrm{~h}, 24 \mathrm{~h}$ & $4{ }^{\circ} \mathrm{C}$ or RT & $\begin{array}{l}\text { Healthy } \\
\text { volunteers }\end{array}$ & $\begin{array}{l}\text { q-PCR for total DNA } \\
\text { conc., DNA integrity } \\
\text { assay (q-PCR) }\end{array}$ & $\begin{array}{l}\text { Increase in total DNA after } 24 \mathrm{~h} \text { but not } \\
6 \mathrm{~h}\left(4^{\circ} \mathrm{C} \text { and RT), altered DNA integrity }\right. \\
(201 / 105 \mathrm{bp} \mathrm{PCR}) \text { at } 24 \mathrm{~h} \text { RT but not } 4^{\circ} \mathrm{C}\end{array}$ \\
\hline [124] & unknown & $\begin{array}{l}\text { More than } \\
14 \text { days }\end{array}$ & Not stated & $\begin{array}{l}\text { Pregnant } \\
\text { women }\end{array}$ & $\begin{array}{l}\text { RHD genotyping } \\
\text { (PCR) }\end{array}$ & $\begin{array}{l}67 / 1896 \text { samples were inconclusive or false } \\
\text { negative, most of them had been stored for } \\
\text { more than } 2 \text { weeks + showed high maternal } \\
\text { background DNA }\end{array}$ \\
\hline [125] & EDTA & Up to 1 day & On ice or at RT & $\begin{array}{l}\text { Healthy } \\
\text { volunteers }\end{array}$ & $\begin{array}{l}\text { PicoGreen assay and } \\
\text { q-PCR }\end{array}$ & $\begin{array}{l}\text { Increase in cfDNA was seen starting at } \\
4 \mathrm{~h} \text { storage independent from storage } \\
\text { temperature }\end{array}$ \\
\hline [126] & EDTA & $\begin{array}{l}\text { Up to } 8 \text { days } \\
\text { shipping } \\
\text { (median } \\
2 \text { days) }\end{array}$ & RT (?) & $\begin{array}{l}\text { Pregnant } \\
\text { women }\end{array}$ & $\begin{array}{l}\text { RHD genotyping } \\
(\mathrm{PCR})\end{array}$ & $\begin{array}{l}\text { Steep increase in total cfDNA conc. starting } \\
\text { with day } 2 \text { of storage but almost no change } \\
\text { in amount of fetal DNA in samples shipped } \\
\text { for } 6 \text { days }\end{array}$ \\
\hline [95] & EDTA & $\begin{array}{l}\text { Shipping } \\
\text { for max of } \\
3 \text { days }\end{array}$ & $\begin{array}{l}\text { RT or in boxes } \\
\text { with frozen gel } \\
\text { packs }\end{array}$ & $\begin{array}{l}\text { Pregnant } \\
\text { women }\end{array}$ & $\begin{array}{l}\text { q-PCR for total and } \\
\text { fetal DNA (SRY) conc. }\end{array}$ & $\begin{array}{l}\text { Quantity of total amount of cfDNA was much } \\
\text { higher at } 3 \text { days independent from shipping } \\
\text { temperature, almost no change in amount of } \\
\text { fetal DNA in shipped samples independent } \\
\text { of temperature }\end{array}$ \\
\hline [127] & EDTA & Up to 2 days & RT & $\begin{array}{l}\text { Pregnant } \\
\text { women }\end{array}$ & $\begin{array}{l}\text { Multiplexed } \\
\text { sequencing (MPS) }\end{array}$ & $\begin{array}{l}\text { Plasma samples stored for } 1 \text { day can reliably } \\
\text { be used for MPS analysis (this method enriches } \\
\text { for short DNA fragments thus removing longer } \\
\text { ones from lysed maternal cells) }\end{array}$ \\
\hline [128] & EDTA & $\begin{array}{l}\text { Shipping } \\
\text { from } 2 \text { to } \\
9 \text { days }\end{array}$ & & $\begin{array}{l}\text { Pregnant } \\
\text { women }\end{array}$ & $\begin{array}{l}\text { RHD genotyping } \\
(\mathrm{PCR})\end{array}$ & $\begin{array}{l}\text { Outdoor temperature }\left(-5^{\circ} \mathrm{C} \text { to } 25^{\circ} \mathrm{C}\right) \text { did } \\
\text { not affect fetal DNA quantity, total DNA level } \\
\text { at mean average temperature } 20^{\circ}-24^{\circ} \mathrm{C} \\
\text { was significantly less than at mean average } \\
\text { temperature of } 24^{\circ}-30^{\circ} \mathrm{C}\end{array}$ \\
\hline [129] & EDTA & $\begin{array}{l}\text { At least } 1 \\
\text { day }\end{array}$ & $4^{\circ} \mathrm{C}$ & $\begin{array}{l}\text { Pregnant } \\
\text { women }\end{array}$ & $\begin{array}{l}\text { RHD genotyping } \\
\text { (PCR) }\end{array}$ & $\begin{array}{l}\text { All samples worked fine for quantification of } \\
S R Y \text { sequence }\end{array}$ \\
\hline [85] & EDTA & 3 days & RT & $\begin{array}{l}\text { NSCLC } \\
\text { patients }\end{array}$ & $\begin{array}{l}\text { Total cfDNA } \\
\text { quantification } \\
\text { (q-PCR) } K \text {-ras } \\
\text { mutation detect-ion } \\
\text { (ARMS PCR) }\end{array}$ & $\begin{array}{l}\text { Strong increase in total DNA quantity at } \\
3 \text { days, detection rate for mutant } K \text {-ras } \\
\text { dropped from } 80 \% \text { to } 40 \% \text { after a } 3 \text {-day } \\
\text { storage }\end{array}$ \\
\hline [104] & EDTA & Up to 2 days & $5{ }^{\circ} \mathrm{C}$ or RT & $\begin{array}{l}\text { Prostate } \\
\text { cancer } \\
\text { patients }\end{array}$ & $\begin{array}{l}\text { Targeted sequencing } \\
\text { (panel of } 305 \text { genes } \\
\text { of interest) }\end{array}$ & $\begin{array}{l}\text { CtDNA level did not change at } 2 \text {-day storage, } \\
\text { copy number alterations and mutational } \\
\text { profiling identical in all samples independent } \\
\text { of storage time and temperature }\end{array}$ \\
\hline [102] & EDTA & Up to 2 days & $4{ }^{\circ} \mathrm{C}$ or RT & $\begin{array}{l}\text { Breast } \\
\text { cancer } \\
\text { patients }\end{array}$ & $\begin{array}{l}\text { Total cfDNA + ctDNA, } \\
\text { DNA quantification by } \\
\text { ddPCR }\end{array}$ & $\begin{array}{l}3 / 6 \text { Patients showed increased amount } \\
\text { of total cfDNA at } 2 \text { days' storage (both } \\
\text { temperatures), } 2 / 4 \text { patients had decreased } \\
\text { tumor allele frequencies at } 2 \text { days' storage } \\
\text { (both temperatures) }\end{array}$ \\
\hline [44] & Serum & Up to 3 days & $\begin{array}{l}\text { Storage on ice } \\
\text { or RT }\end{array}$ & $\begin{array}{l}\text { Healthy } \\
\text { people } \\
\text { and cancer } \\
\text { patients }\end{array}$ & $\begin{array}{l}\text { Quantification of cell- } \\
\text { free nucleosomes } \\
\text { containing 5-methyl- } \\
\text { cytosine DNA or } \\
\text { histone modification } \\
\text { H3K9Me3 (ELISA) }\end{array}$ & $\begin{array}{l}\text { Samples kept at RT had significantly } \\
\text { higher values than samples stored on ice } \\
\text { independent of storage time }\end{array}$ \\
\hline
\end{tabular}


Table 5 (continued)

\begin{tabular}{|c|c|c|c|c|c|c|}
\hline Ref & Tube & Storage time & $\begin{array}{l}\text { Storage } \\
\text { temperature }\end{array}$ & Samples & Method & Remarks \\
\hline [130] & EDTA & 1 day & $4{ }^{\circ} \mathrm{C}$ or RT & $\begin{array}{l}\text { NSCLC } \\
\text { patients }\end{array}$ & $\begin{array}{l}\text { Total DNA } \\
\text { quantification } \\
\text { (Qubit) + mutation } \\
\text { detection (ddPCR) }\end{array}$ & $\begin{array}{l}\text { No difference in total cfDNA amount, same } \\
\text { for mutation detection }\end{array}$ \\
\hline [110] & EDTA & Up to 4 days & $\mathrm{RT}(?)$ & $\begin{array}{l}\text { Cancer } \\
\text { patients }\end{array}$ & $\begin{array}{l}\text { Variant allele } \\
\text { frequency was } \\
\text { determined by } \\
\text { Sanger sequencing } \\
\text { or NGS }\end{array}$ & $\begin{array}{l}\text { There was a significant increase in total } \\
\text { cfDNA conc. in samples processed at } 4 \text { days, } \\
\text { these were predominantly larger DNA } \\
\text { fragments, nevertheless somatic variants } \\
\text { detected in the } 1 \text {-h sample were found in } \\
\text { 96-h samples as well }\end{array}$ \\
\hline [111] & EDTA & Up to 1 day & RT & $\begin{array}{l}\text { Healthy } \\
\text { people } \\
\text { and NSCLC } \\
\text { patients }\end{array}$ & $\begin{array}{l}\text { Total DNA } \\
\text { quantification (Qubit) }\end{array}$ & No change in total cfDNA amount over time \\
\hline [87] & EDTA & Up to 1 week & $4{ }^{\circ} \mathrm{C}$ or RT & $\begin{array}{l}\text { Cancer } \\
\text { patients }\end{array}$ & $\begin{array}{l}\text { Total DNA } \\
\text { quantification + } \\
\text { mutant detection } \\
(\text { TP53 + PIK3CA) with } \\
\text { digital PCR }\end{array}$ & $\begin{array}{l}\text { Levels of total cfDNA increased over time } \\
\text { while fraction of ctDNA decreased (absolute } \\
\text { number of mutant DNA copies were stable } \\
\text { over time), storage at } 4^{\circ} \mathrm{C} \text { for up to } 2 \text { days } \\
\text { increased the level of total cfDNA quantity } \\
\text { but less than storage at RT, } 4 \text {-day storage } \\
\text { at } 4^{\circ} \mathrm{C} \text { showed significant increase in total } \\
\text { cfDNA }\end{array}$ \\
\hline [131] & EDTA & Up to $12 \mathrm{~h}$ & RT & $\begin{array}{l}\text { NSCLC } \\
\text { patients }\end{array}$ & $\begin{array}{l}\text { Total DNA } \\
\text { quantification } \\
\text { (Qubit) + mutant } \\
\text { detection (NGS- } \\
\text { targeted sequencing) }\end{array}$ & $\begin{array}{l}\text { Increased level of total cfDNA conc. was } \\
\text { found as early after } 8-12 \mathrm{~h} \text { storage, storage } \\
\text { for }>4 \mathrm{~h} \text { lead to decreased detection of } \\
\text { mutant DNA which contrasts the majority of } \\
\text { other papers }\end{array}$ \\
\hline
\end{tabular}

ARMS, amplification refractory mutation system; cfDNA, cell-free DNA; CtDNA, circulating tumor DNA; ddPCR, droplet digital PCR; EDTA, ethylenediaminetetraacetic acid; ELISA, enzyme-linked immunosorbent assay; NGS, next-generation sequencing; NSCLC, non-small cell lung carcinoma; PCR, polymerase chain reaction; q-PCR, quantitative PCR; RT, room temperature.

reason for these contradicting results is caused by the use of individual plasma samples from healthy and diseased subjects. It is commonplace that blood is an extremely complex liquid and its composition is highly variable. For this reason, the use of plasma/serum pools instead of single blood samples for long-term storage experiments might be a good alternative. Recently, it was demonstrated that plasma samples with a low mutant AF degrade faster during storage than samples with a high mutant AF, supporting the assumption that individual samples behave very differently [93]. The storage of extracted cfDNA in a dry form (such as paper-based matrices) as compared to the usual storage in a liquid might be a viable alternative as shown by Heider and colleagues [149].

So far, only a few papers were published in which the effect of freeze-thaw cycles on cfDNA was analyzed. The effect of freezing and thawing of plasma samples up to 3 times did not have an effect on plasma cfDNA concentration [123]. Additionally, freezing and thawing of plasma samples once did not change the DNA integrity index (DNA-II) (measured as the ratio of the amount of $201 \mathrm{bp}$ and $105 \mathrm{bp}$ amplicons of the LEPTIN B gene). In contrast, freezing and thawing of plasma samples up to 3 times had a significant effect on DNA integrity probably due to fragmentation, but treatment of extracted DNA the same way $(3 \times$ freeze-thaw $)$ had no effect. In one of the first reports on the detection of cell-free serum RNA, it was demonstrated that tyrosinase mRNA survived one freezing/thawing cycle but was undetectable after three cycles [138]. The decision to aliquot samples in larger $(>3 \mathrm{~mL}$ and more) or smaller $(<100 \mu \mathrm{L}$ or less) volume tubes is strongly dependent on the downstream application and should be performed accordingly. If it were known that an analysis method requires the usage of a large plasma volume and frozen samples have to be thawed only once, it would be a waste of time (not to mention increased costs) to aliquot samples in small-volume containers as usually recommended. 
Table 6: Effects of long-term storage of cell-free matrix on cfDNA.

\begin{tabular}{|c|c|c|c|}
\hline Reference & Samples & Storage condition & Detection method \\
\hline [137] & $\begin{array}{l}\text { Plasma and serum from healthy } \\
\text { volunteers and cancer patients }\end{array}$ & $-70^{\circ} \mathrm{C}$ & $\begin{array}{l}\text { Nested PCR and gel } \\
\text { electrophoresis }\end{array}$ \\
\hline [138] & Serum from cancer patients & $-70^{\circ} \mathrm{C}$ & $\begin{array}{l}\text { Reverse transcription, } \\
\text { nested PCR and gel } \\
\text { electrophoresis }\end{array}$ \\
\hline [139] & $\begin{array}{l}\text { Sera and amniotic fluid from } \\
\text { pregnant women }\end{array}$ & $-20^{\circ} \mathrm{C}$ & q-PCR (DYS1 locus) \\
\hline [140] & $\begin{array}{l}\text { Plasma from healthy volunteers, } \\
\text { lung cancer patients and heavy } \\
\text { smokers }\end{array}$ & $\begin{array}{l}-80{ }^{\circ} \mathrm{C} \text { for plasma } \\
\text { and }-20{ }^{\circ} \mathrm{C} \text { for } \\
\text { isolated DNA }\end{array}$ & $\mathrm{q}-\mathrm{PCR}(h T E R T)$ \\
\hline$[123]^{\mathrm{a}}$ & Plasma from healthy volunteers & $-80^{\circ} \mathrm{C}$ & q-PCR (leptin gene) \\
\hline [141] & Plasma from pregnant women & $\begin{array}{l}-20^{\circ} \mathrm{C} \text { for at least } \\
4 \text { years }\end{array}$ & $\begin{array}{l}\text { Total and fetal DNA } \\
\text { conc. (q-PCR) }\end{array}$ \\
\hline [142] & $\begin{array}{l}\text { Serum samples from cancer } \\
\text { patients }\end{array}$ & $-70^{\circ} \mathrm{C}$ & $\begin{array}{l}\text { Quantitation of } \\
\text { nucleosomes by ELISA }\end{array}$ \\
\hline [143] & Serum from cancer patients & $-20^{\circ} \mathrm{C}$ and $-80^{\circ} \mathrm{C}$ & $\begin{array}{l}\text { Panel of different } \\
\text { miRNAs }\end{array}$ \\
\hline
\end{tabular}

[84] Plasma from cancer patients

$[144]^{b} \quad$ Plasma from healthy individuals
Plasma from healthy people spiked with DNA from MCF-7 or SKBR3 cells, sodium bisulfitetreated DNA from spiked plasma (MCF-7 cells) was stored at $-80^{\circ} \mathrm{C}$ $-80^{\circ} \mathrm{C}$ for more than 12 years

Short range: Up to $3 \mathrm{~h}$ at $80^{\circ} \mathrm{C}$, $-20^{\circ} \mathrm{C},+4^{\circ} \mathrm{C}$, and $\mathrm{RT}$ long range: plasma storage at $-80^{\circ} \mathrm{C}$ for 9 months, storage of extracted cfDNA for up to 5 months at $-20^{\circ} \mathrm{C}$

$-80^{\circ} \mathrm{C}$ for up to 21 months

RT, $4^{\circ} \mathrm{C},-80^{\circ} \mathrm{C}$

$-80{ }^{\circ} \mathrm{C}$ for up to 8 months (spiked plasma)
Remarks

In 4/16 plasma/serum samples stored for more than 6 years $K$-ras mutations were found (no data presented on decay rate/ loss over time)

Tumor-associated gene expression (tyrosinase mRNA) was detected in sera stored for $>2$ years

There was a loss of $0.66 \mathrm{GE} / \mathrm{mL}$ per month of storage in serum, this was not seen in amniotic fluid samples Yearly decay rate for isolated DNA was $30.5 \%$ and for DNA from stored plasma $30.7 \%$

No change in DNA conc. and in DNA integrity (201 bp/105 bp, 365 bp/105 bp) was seen (after 2 weeks storage) Amplification of fetal DNA (amplicon sizes from $63 \mathrm{bp}$ to $524 \mathrm{bp}$ ) showed no change after 4 years of storage (compared to samples analyzed 1 month after blood draw) Nucleosome loss was $7 \%$ /year at $70{ }^{\circ} \mathrm{C}$

(5-year period)

10-day storage did not change miRNA conc. at either temperature, 20-month storage did not change total RNA conc. but several miRNAs were affected by storage conditions (temperature), storage of up to 10 years at $-20^{\circ} \mathrm{C}$ showed no decrease at 4 years but significant decrease after 6 years and longer

Panel of miRNA (TLDA)

In a fresh sample pool, 202 miRNA were detected and in the stored pool 177 miRNA, the $C_{T}$ values were comparable in both pools

q-PCR targeting BRAF (short amplicon 105 bp, long $288 \mathrm{bp}$ )

$3 \mathrm{~h}$ experiment: Storage at $4^{\circ} \mathrm{C}$ gave the highest yield for long amplicon, no change for short-sized amplicon, storage at $4{ }^{\circ} \mathrm{C}$ and RT led to slight decrease in DNA integrity, Long-term experiment: no change in cfDNA conc. after 9 months storage, slight decrease in conc. after storage of extracted cfDNA for 5 months

Quantification of total amount of cfDNA by q-PCR

Quantification of total + fetal DNA conc. (q-PCR)

Real-time MSP or WGA

Mean decrease of $38 \%$ in total cfDNA was seen

RT storage of plasma for 2 weeks did not change fetal DNA quantity, holds true for storage at $4^{\circ} \mathrm{C}$ for 3 days and $-80^{\circ} \mathrm{C}$ for 2 weeks

Plasma storage for 3 months had no influence on ctDNA analysis, 8-month storage led to a decrease in methylated ctDNA, bisulfite-converted DNA can be stored for 1 year at $-20^{\circ} \mathrm{C}$ or $-80^{\circ} \mathrm{C}$ without any effect on real-time MSP analysis 
Table 6 (continued)

\begin{tabular}{|c|c|c|c|c|}
\hline Reference & Samples & Storage condition & Detection method & Remarks \\
\hline [93] & Plasma from cancer patients & $\begin{array}{l}-20^{\circ} \mathrm{C} \text { (isolated } \\
\text { cfDNA) or }-80^{\circ} \mathrm{C} \\
\text { (plasma) }\end{array}$ & $\begin{array}{l}\text { Detection of EGFR gene } \\
\text { mutations (L858R and } \\
\text { T790M) by mutation- } \\
\text { biased PCR and } \\
\text { quench probe system } \\
\text { (in-house) }\end{array}$ & $\begin{array}{l}\text { Decrease in EGFR mutation in isolated } \\
\text { cfDNA was } 20-25 \% \text { and in plasma } \\
35-40 \% \text { reduction, respectively, after } \\
7 \text { years of storage }\end{array}$ \\
\hline [119] & $\begin{array}{l}\text { Whole blood from healthy donors } \\
\text { drawn into } \mathrm{K}_{2} \text { EDTA, Streck cell- } \\
\text { free DNA tube or PAXgene Blood } \\
\text { ccfDNA tube was spiked with DNA } \\
\text { from different pathogens }\end{array}$ & $\begin{array}{r}24 \text { weeks at } \\
-80^{\circ} \mathrm{C}\end{array}$ & $\begin{array}{l}\text { Real-time PCR with } \\
\text { pathogen-specific } \\
\text { primers }\end{array}$ & $\begin{array}{l}\text { No change in Ct values when compared to } \\
\text { fresh samples }\end{array}$ \\
\hline [148] & $\begin{array}{l}\text { Plasma from breast cancer } \\
\text { patients }\end{array}$ & 14 days at $-80^{\circ} \mathrm{C}$ & $\begin{array}{l}\text { Copy number alteration } \\
\text { analysis (NGS) and } \\
\text { SNV analysis (QIASeq } \\
\text { Target DNA Breast } \\
\text { Cancer Panel) }\end{array}$ & $\begin{array}{l}\text { Freezing showed no significant statistical } \\
\text { difference on the cfDNA yield, total number } \\
\text { of aligned reads, percentage of aligned } \\
\text { reads, and CNV quality score and did not } \\
\text { affect the results of SNV analysis }\end{array}$ \\
\hline
\end{tabular}

aThe authors also conclude that DNA appears to be more resistant to fragmentation when stored in DNA extraction solution than in plasma. ${ }^{b}$ The decrease in the yield of long-sized amplicons after storage for $3 \mathrm{~h}$ at $-20^{\circ} \mathrm{C}$ or $-80^{\circ} \mathrm{C}$ is probably not due to storage itself but caused by freezing and thawing the samples once. cfDNA, cell-free DNA; ctDNA, circulating tumor DNA; ELISA, enzyme-linked immunosorbent assay; GE, genome equivalents; miRNAs, micro RNAs; MSP, methylation-specific PCR; NGS, next-generation sequencing; PCR, polymerase chain reaction; q-PCR, quantitative PCR; SNV, single-nucleotide variation; TLDA, TaqMan low-density array; WGA, whole genome amplification.

As the impact of long-term storage has not been examined in detail so far, we need more studies and data to answer these questions:

- What are the optimal storage conditions (time, temperature) for cell-free matrices and extracted cfDNA samples?

- Does the thawing procedure (duration, i.e. fast vs. slow, temperature) have an effect on cfDNA quantity/ quality?

Proposals: In order to make results from longitudinal analyses comparable, the time of sampling should be about the same for the whole group.

It would be very helpful to develop decay markers as a surrogate for deterioration of cfDNA upon handling and storage.

\section{Is DNA quantification and determination of cfDNA fragmentation a useful tool?}

As stated before, an increase in the quantity of cfDNA is not only seen in tumor patients but in other conditions as well. These are (just to mention a few examples) patients with myocardial infarction [150], an ischemic stroke [151], trauma patients [152] and healthy subjects who exercise extensively [153]. Additionally, it was demonstrated that the amount of cfDNA depends on many intrinsic as well as extrinsic factors (such as DNA extraction method, see following text) and that there is large overlap in the quantity of cfDNA in patients with a malignant or benign disease and frequently also with healthy people [154]. There are several different quantification methods in use differing in their DNA concentration (see below) which needs to be considered [155].

In one of the earliest reports analyzing the fragment size of cfDNA, these molecules were examined by electron microscopy and a median strand length of $273 \mathrm{~nm}$ in healthy subjects and $185 \mathrm{~nm}$ in pancreatic cancer patients was described [156]. This observation was later confirmed and found that cfDNA from tumor patients is more fragmented than from healthy people and that tumor-associated cfDNA (ctDNA) consists of smaller fragments [157-159]. On the other hand, there are reports in which mutant ctDNA was also detected in long fragments (1-9 kb) and that the yield of mutant ctDNA is dependent on the isolation method [160]. Plasma samples from hepatocellular carcinoma (HCC) patients showed a correlation between the amount of short DNA fragments (less than $150 \mathrm{bp}$ ) and a larger amount of tumor DNA and vice versa, i.e. a lower quantity of tumor DNA is associated with increased fragment length [161]. In addition, Vagner et al. [162] isolated large extracellular vesicles (EV) from 
prostate cancer patients and showed that they contain chromosomal DNA of up to $2 \times 10^{6} \mathrm{bp}$ long, thereby reflecting the complete genetic make-up of the cells of origin. These large vesicles seem to be tumor-specific, as they were not found in plasma from healthy people.

The measurement of the DNA-II (ratio of ALU $115 \mathrm{bp}$ vs. $247 \mathrm{bp}$ amplicon) obtained from cell-free supernatants from subjects with undiagnosed pleural effusions demonstrated a higher DNA-II in patients with a malignant pleural effusion when compared to patients with a benign effusion. It was concluded that this method could be useful especially in cases where the pleural aspirate cytology is negative [163]. This approach could be a useful tool in clinical practice, but unfortunately there exist so far no more data to confirm this result.

These observations lead us to the question whether the measurement of DNA fragmentation in plasma samples from patients is a meaningful tool. Wang and colleagues were the first to describe an increased DNA integrity in plasma from cancer patients as compared to a control group consisting of patients with a variety of different non-neoplastic diseases as well as healthy people [164]. The authors conclude that "the increased DNA integrity in plasma DNA is associated with cancer, and measurement of DNA integrity may provide a simple and inexpensive measure for cancer detection, including their ability to discriminate this group from a healthy control population”. Another group confirmed this data but found a very large overlap in the DNA-II between healthy people and women with a benign breast disease [165]. After the first description on the usefulness of the measurement of DNA integrity for the discrimination of cancer patients from controls, a surge of more than 50 papers were published, some of them corroborating the original results while others were not able to find a difference between patients with and without cancer.

From our own experience, the quantification of isolated cfDNA makes sense particularly when time-consuming and or expensive downstream applications are planned. In these cases, we would recommend a quantitative PCR (q-PCR) (or even digital PCR [dPCR] for absolute quantification) instead of spectrophotometry or fluorometric methods as it was shown that there is a good correlation between serum cfDNA concentration measured by PicoGreen and qPCR but only a weak correlation between spectrophotometry and PicoGreen [166]. Others confirmed this observation in that the accordance between PicoGreen staining and different real-time PCR methods (SybrGreen and TaqMan probe) was rather weak [167].

In conclusion, we need a much deeper understanding about the release mechanisms of cfDNA, what these molecules look like and in which forms they are present in the blood stream. As long as we have only a rudimentary understanding of the factors determining these mechanisms, we will not be able to answer the question whether the determination of the DNA integrity might be a clinically meaningful tool.

\section{Choice of matrix - plasma vs. serum vs. other body fluids}

Cell-free nucleic acids (of which the majority is usually from healthy cells) containing DNA with tumor-associated alterations (ctDNA) can be isolated not only from plasma and serum, but from other body fluids like ascites, breast milk, lymphatic and peritoneal fluids, bone marrow aspirates, urine, prostatic fluid, peritoneal lavage, sputum, cerebrospinal fluid, gastric juice, and biliary and stool samples as well [154]. In patients with hematological tumors, it seems obvious to use plasma or serum as starting material for a genetic analysis of cfDNA. The same holds for urine in patients with a disease of the urogenital tract $[8,168]$. Sputum is an interesting target liquid to be used specifically for patients with head and neck diseases, with respiratory tract or bronchopulmonary cancers [169171]. An interesting approach was recently published by $\mathrm{Wu}$ and colleagues [170] who looked for mutant driver gene alterations by next-generation sequencing (NGS) in tissue, plasma, sputum and urine of non-small cell lung carcinoma (NSCLC) patients. They found a concordance rate between tissue and cfDNA from the different liquids of $86 \%$ (plasma) to $70 \%$ (urine). When they combined the data for all liquids, the concordance rose to $90 \%$. Unfortunately, this approach might not be useful for a daily routine as it takes more time and effort and is associated with higher costs. The analysis of cfDNA in a malignant pleural effusion from cancer patients was shown to be as successful as the examination of plasma from these patients. This holds not only for lung cancer patients [172] but has been demonstrated in a gastric cancer patient also [173].

The observation that the amount of cfDNA in serum vs. paired plasma is several fold higher had been described by Lo et al. in pregnant women [53, 174]. This was later confirmed in healthy people $[90,121,111]$, in bone marrow transplantation patients [80] and in patients with a CRC metastasized to the liver [175]. For the question whether plasma or serum is better suited for a molecular analysis of cfDNA, there can be no universal "correct" answer, as this depends on the target/s and the method of analysis. 
Vallee and coworkers answered this question in favor of plasma when they looked for mutations in the EGFR gene in NSCLC patients [176]. They found an activating EGFR mutation in $95 \%$ of the plasma samples and $72 \%$ in serum. A similar observation (i.e. higher quantity of ctDNA in plasma than serum) was made in a mouse xenograft model in which the amount of mutant DNA (KRAS and PSAT1) in serum and plasma was compared [177]. When Kobayashi and coworkers looked for EGFR T790M mutations in plasma and serum of NSCLC patients, they found a higher specificity in serum (67\%) than in plasma (50\%), but the test sensitivity was the same for both liquids [178]. Mayo de Las Casas also looked for EGFR mutations in cfDNA and detected them in higher frequencies in plasma than in serum, but in $8 \%$ of the patients these alterations were found exclusively in serum [179]. These patients would not have received a targeted therapy if only plasma had been analyzed. Similar observations were reported for $B R A F$ mutations in melanoma patients in whom the amount of tumor-derived DNA in plasma was significantly higher than in serum [180]. The comparison of plasma and serum from patients with metastatic CRC demonstrated that the fraction of ctDNA is higher in plasma and this matrix is better suited for the methylation and mutation analysis [181]. For the examination of EV, plasma and serum samples have been used [182], whereas many groups seem to prefer serum for the analysis of micro RNAs (miRNAs). Therefore, it looks as if plasma is the preferred choice for the detection of mutations in cfDNA.

When compared to the data on how to handle plasma/serum in a way to enable the optimal analysis of cfDNA, other body liquids do very poorly. Recently, it has been demonstrated that CSF is a valuable source for the molecular genetic analysis in patients who suffer from primary brain tumors or from metastases to the brain. Pan et al. [183] looked for mutations in CSF and plasma and observed a higher mutant $\mathrm{AF}$ in the former. In addition, they detected some alterations in plasma not found in CSF. So far, it is unknown whether the mutant AF in these patients was higher in plasma and/or whether the bloodbrain barrier played a role. When both fluids are available, it might therefore be a good idea to analyze both [13]. Pentsova et al. [184] sequenced cfDNA from cell-free CSF supernatant and the corresponding genomic DNA from the cell pellet and found a higher percentage of sequence reads in the supernatant than in the CSF pellet (a similar observation was described for the analysis of microsatellites in cell-free bronchial lavage fluid and the corresponding cell pellet by Schmidt et al.) [17]. For patients afflicted with a brain tumor, the examination of CSF seems to be more useful than plasma as more tumor-associated alterations are found in the former liquid than in plasma [157, 185-187]. A similar observation was made not only for patients with a primary brain tumor but also in lung cancer patients with leptomeningeal metastases in whom more mutations were found in CSF than in plasma [188]. Unfortunately, there is no optimized standard protocol for CSF collection, preparation, biomarker isolation and data analysis [12].

Urine is a body fluid which can be collected noninvasively and seems to be a valuable source for cfDNA in patients with a benign and a malignant disease as well as for the isolation and analysis of cell-free fetal DNA [189]. Nevertheless, our knowledge on the best strategy for the acquisition, handling and processing of urine for the analysis of extracellular nucleic acids from this fluid is still very limited. This starts with the question when to collect urine (time of the day), the usage of first-void morning samples rather than second void, midstream vs. total void and whether to use preservatives or not. So far, it is not clear whether urine needs to be processed as soon as possible after collection or if storage is possible, and when the answer is yes, under which conditions. Bosschieter et al. aimed to establish a protocol for urine collection and storage before analysis. When the samples were stored at $4^{\circ} \mathrm{C}$ for 2 days, no preservation substances were necessary but storage at RT for 7 days without any additive (either $40 \mathrm{mM}$ EDTA or urine conditioning buffer from Zymo Research) led to a strong decrease in cfDNA (Qubit dsDNA kit) [190]. Freezing the samples at $-20^{\circ} \mathrm{C}$ or $-80^{\circ} \mathrm{C}$ with or without any preservative did not lead to a decrease in the total DNA quantity. Additionally, when urine from a group of patients with NSCLC or bladder cancer was stored for 7 days at RT in the presence/absence of EDTA, a strong decrease in methylated DNA was found in the samples which were stored without any additive. Similar results, i.e. no change in the total amount of DNA in urine supernatant from bladder cancer patients, which had been stored for 7 days at RT in containers containing a proprietary preservative, were reported by Li et al. [191].

\section{DNA isolation}

As we have to assume that in the majority of cases the quantity of ctDNA in body liquids is very low, that cfDNA is a priori in a "poor shape" (i.e. highly fragmented) and that there is no method to predict the percentage of ctDNA, it is absolutely necessary to aim for the highest DNA isolation efficiency. In recent years, several companies developed a range of DNA isolation kits of which only the "dedicated" 
kits were recommended for the extraction of cfDNA [192]. In several papers, a variety of different kits were compared [84, 85, 93, 193-204]. From these results, one can conclude that bead-based isolation methods worked somewhat better than membrane-based kits and that the former ones are especially useful for the isolation of low-molecularweight DNA. A similar conclusion was recently reported for the isolation of cfDNA from urine [45]. It is important to keep in mind that the DNA yield and purity of these "dedicated" kits show a high variability depending on the method of the isolation procedure. In addition, these kits show a variety depending on the body liquid used for DNA isolation (plasma, urine, CSF).

In order to establish a reliable standard for q-PCR or dPCR quantification, we would recommend the use of DNA resembling cfDNA as much as possible (such as highly fragmented genomic DNA). As this field is very much in movement and there are constantly new DNA isolation kits introduced, it seems too early to recommend a specific kit for a specific task/method.

\section{Trials for the establishment of quality assessments}

Already in 2015, the European Committee for Standardization published the Technical Specification DIN CEN/ TS 16835 (https://www.cen.eu/work/products/TS/Pages/ default.aspx). In part 3 (Isolated circulating cell-free DNA from plasma), it is stated that the storage time before plasma processing should not exceed $6 \mathrm{~h}$. The authors of this guideline also recommend the use of blood collection tubes stabilizing cfDNA, especially if there is a longer delay between blood draw and plasma preparation. Additionally, a two-step centrifugation protocol (low- and highspeed centrifugation) for cell removal is recommended.

Recently, two external quality assessment schemes for the isolation and analysis of ctDNA harboring an EGFR mutation were published $[205,206]$. These initiatives are highly welcome but unfortunately take the second step before the first as the focus is on the analytical quality, thus leaving out all pre-analytical steps associated with probe sampling and handling. A study initiated by Malentacchi and colleagues a few years ago had sent out plasma samples to participating laboratories across Europe and analyzed the quantity and quality of different isolation methods used by q-PCR [192]. A similar approach was recently published by Keppens et al. who had distributed plasma samples with spiked-in mutant DNA (EGFR and/ or $\mathrm{K}$-ras/N-ras mutation) to 32 laboratories [207]. The labs then used their preferred method for DNA extraction and analysis and reported the results back. As important and interesting as these trials are, they still leave us in a state of limbo on all preceding pre-analytical steps. In addition to these initiatives, a working group of the European Federation for Clinical Chemistry and Laboratory Medicine is trying to improve the harmonization in the pre-analytical phase across European member societies [208-210].

\section{Final remarks}

The generated data over the recent years on pre-analytical issues related to the use of cell-free nucleic acids are indeed impressive. Nevertheless, there are large gaps in our understanding of the basic mechanisms of cfDNA such as release, composition and distribution in different body liquids, stability and their biological function. In addition, we need to identify the most critical preanalytical parameters for the preparation of body liquids to be used for the analysis of cell-free nucleic acids [211]. Only if we close these gaps we will be able to establish SOPs for the optimal handling of liquid biopsy samples to obtain a maximum of information in a molecular analysis of cell-free nucleic acids. We expect that an agreement on the optimal methods for the use of blood-drawing tubes (EDTA vs. blood-stabilizing tubes) to enable a delayed processing, and the efficient and complete removal of cells and cell debris from body liquids will be the easiest to achieve. This will be the first step for a broad application of liquid biopsy as part of a daily clinical routine method.

Research funding: None declared.

Author contributions: All authors have accepted responsibility for the entire content of this manuscript and approved its submission.

Competing interests: Authors state no conflict of interest.

\section{References}

1. Dagher G, Becker KF, Bonin S, Foy C, Gelmini S, Kubista M, et al. Pre-analytical processes in medical diagnostics: new regulatory requirements and standards. N Biotechnol 2019;52:121-5.

2. Temilola DO, Wium M, Coulidiati TH, Adeola HA, Carbone GM, Catapano CV, et al. The prospect and challenges to the flow of liquid biopsy in Africa. Cells 2019;8:862.

3. Merker JD, Devereaux K, Iafrate AJ, Kamel-Reid S, Kim AS, Moncur JT, et al. Proficiency testing of standardized samples shows very high interlaboratory agreement for clinical next-generation sequencing-based oncology assays. Arch Pathol Lab Med 2019;143:463-71. 
4. Grace MR, Hardisty E, Dotters-Katz SK, Vora NL, Kuller JA. CellFree DNA Screening: complexities and challenges of clinical implementation. Obstet Gynecol Surv 2016;71:477-87.

5. Finotti A, Allegretti M, Gasparello J, Giacomini P, Spandidos DA, Spoto G, et al. Liquid biopsy and PCR-free ultrasensitive detection systems in oncology (Review). Int J Oncol 2018;53:1395-434.

6. Trigg RM, Martinson LJ, Parpart-Li S, Shaw JA. Factors that influence quality and yield of circulating-free DNA: a systematic review of the methodology literature. Heliyon 2018;4:e00699.

7. Martignano F. Cell-free DNA: an overview of sample types and isolation procedures. Methods Mol Biol 2019;1909:13-27.

8. Larsen LK, Lind GE, Guldberg P, Dahl C. DNA-methylation-based detection of urological cancer in urine: overview of biomarkers and considerations on biomarker design, source of dna, and detection technologies. Int J Mol Sci 2019;20:2657.

9. Burnham P, Dadhania D, Heyang M, Chen F, Westblade LF, Suthanthiran M, et al. Urinary cell-free DNA is a versatile analyte for monitoring infections of the urinary tract. Nat Commun 2018;9:2412.

10. Wang XS, Zhao MQ, Zhang L, Kong DJ, Ding XZ, Hu XC, et al. Cell-free DNA in blood and urine as a diagnostic tool for bladder cancer: a meta-analysis. Am J Transl Res 2018;10:1935-48.

11. Hickmann AK, Frick M, Hadaschik D, Battke F, Bittl M, Ganslandt 0 , et al. Molecular tumor analysis and liquid biopsy: a feasibility investigation analyzing circulating tumor DNA in patients with central nervous system lymphomas. BMC Cancer 2019;19:192.

12. Zorofchian S, Iqbal F, Rao M, Aung PP, Esquenazi Y, Ballester LY. Circulating tumour DNA, microRNA and metabolites in cerebrospinal fluid as biomarkers for central nervous system malignancies. J Clin Pathol 2019;72:271-80.

13. Husain H, Nykin D, Bui N, Quan D, Gomez G, Woodward B, et al. Cell-free DNA from ascites and pleural effusions: molecular insights into genomic aberrations and disease biology. Mol Cancer Ther 2017;16:948-55.

14. Lee JS, Hur JY, Kim IA, Kim HJ, Choi CM, Lee JC, et al. Liquid biopsy using the supernatant of a pleural effusion for EGFR genotyping in pulmonary adenocarcinoma patients: a comparison between cell-free DNA and extracellular vesicle-derived DNA. BMC Cancer 2018;18:1236.

15. Arantes LM, De Carvalho AC, Melendez ME, Lopes CA. Serum, plasma and saliva biomarkers for head and neck cancer. Expert Rev Mol Diagn 2018;18:85-112.

16. Hyun KA, Gwak H, Lee J, Kwak B, Jung HI. Salivary exosome and cell-free DNA for cancer detection. Micromachines (Basel) 2018;9:340.

17. Schmidt B, Carstensen T, Engel E, Jandrig B, Witt C, Fleischhacker M. Detection of cell-free nucleic acids in bronchial lavage fluid supernatants from patients with lung cancer. Eur J Cancer 2004;40:452-60.

18. Ye W, Hannigan B, Zalles S, Mehrotra M, Barkoh BA, Williams $M D$, et al. Centrifuged supernatants from FNA provide a liquid biopsy option for clinical next-generation sequencing of thyroid nodules. Cancer Cytopathol 2019;127:146-60.

19. Gahan PB, Stroun M. The virtosome-a novel cytosolic informative entity and intercellular messenger. Cell Biochem Funct 2010;28:529-38.

20. Anker P, Jachertz D, Maurice PA, Stroun M. Nude mice injected with DNA released by antigen stimulated human T lymphocytes produce specific antibodies expressing human characteristics. Cell Biochem Funct 1984;2:33-7.
21. Bendich A, Wilczok T, Borenfreund E. Circulating DNA as a possible factor in oncogenesis. Science 1965;148:374-6.

22. Gartler SM. Cellular uptake of deoxyribonucleic acid by human tissue culture cells. Nature 1959;184(Suppl 19):1505-6.

23. Scharfe-Nugent A, Corr SC, Carpenter SB, Keogh L, Doyle B, Martin C, et al. TLR9 provokes inflammation in response to fetal DNA: mechanism for fetal loss in preterm birth and preeclampsia. J Immunol 2012;188:5706-12.

24. Torralba D, Baixauli F, Villarroya-Beltri C, Fernandez-Delgado I, Latorre-Pellicer A, Acin-Perez R, et al. Priming of dendritic cells by DNA-containing extracellular vesicles from activated T cells through antigen-driven contacts. Nat Commun 2018;9:2658.

25. Garcia-Olmo DC, Dominguez C, Garcia-Arranz M, Anker P, Stroun M, Garcia-Verdugo JM, et al. Cell-free nucleic acids circulating in the plasma of colorectal cancer patients induce the oncogenic transformation of susceptible cultured cells. Cancer Res 2010;70:560-7.

26. Garcia-Olmo D, Garcia-Olmo DC, Ontanon J, Martinez E. Horizontal transfer of DNA and the "genometastasis hypothesis". Blood 2000;95:724-5.

27. Garcia-Olmo D, Garcia-Olmo DC, Ontanon J, Martinez E, Vallejo M. Tumor DNA circulating in the plasma might play a role in metastasis. The hypothesis of the genometastasis. Histol Histopathol 1999;14:1159-64.

28. Chaudhary S, Mittra I. Cell-free chromatin: a newly described mediator of systemic inflammation. J Biosci 2019;44:32.

29. Mittra I, Pal K, Pancholi N, Shaikh A, Rane B, Tidke P, et al. Prevention of chemotherapy toxicity by agents that neutralize or degrade cell-free chromatin. Ann Oncol 2017;28:2119-27.

30. Ermakov AV, Konkova MS, Kostyuk SV, Izevskaya VL, Baranova A, Veiko NN. Oxidized extracellular DNA as a stress signal in human cells. Oxid Med Cell Longev 2013;2013:649747.

31. Aucamp J, Bronkhorst AJ, Badenhorst CP, Pretorius PJ. The diverse origins of circulating cell-free DNA in the human body: a critical re-evaluation of the literature. Biol Rev Camb Philos Soc 2018;93:1649-83.

32. Mandel P, Metais P. Les acides nucleiques du plasma sanguin chez l'homme. C R Acad Sci Paris 1948;142:241-3.

33. Bettegowda C, Sausen M, Leary RJ, Kinde I, Wang Y, Agrawal N, et al. Detection of circulating tumor DNA in early- and late-stage human malignancies. Sci Transl Med 2014;6:224ra24.

34. Bret L, Lule J, Pourrat JP, Fournie GJ. Extracellular DNA in blood and urine as a potential marker for cytotoxicity and nephrotoxicity in the mouse. Ren Fail 1990;12:133-9.

35. Lin SY, Linehan JA, Wilson TG, Hoon DS. Emerging utility of urinary cell-free nucleic acid biomarkers for prostate, bladder, and renal cancers. Eur Urol Focus 2017;3:265-72.

36. Jain S, Lin SY, Song W, Su YH. Urine-based liquid biopsy for nonurological cancers. Genet Test Mol Biomarkers 2019;23: 277-83.

37. Anker P, Stroun M, Maurice PA. Spontaneous extracellular synthesis of DNA released by human blood lymphocytes. Cancer Res 1976;36:2832-9.

38. Laktionov PP, Tamkovich SN, Rykova EY, Bryzgunova OE, Starikov AV, Kuznetsova NP, et al. Cell-surface-bound nucleic acids: free and cell-surface-bound nucleic acids in blood of healthy donors and breast cancer patients. Ann N Y Acad Sci 2004;1022:221-7.

39. Tamkovich SN, Bryzgunova OE, Rykova EY, Permyakova VI, Vlassov VV, Laktionov PP. Circulating nucleic acids in blood of healthy male and female donors. Clin Chem 2005;51:1317-9. 
40. Fernando MR, Jiang C, Krzyzanowski GD, Ryan WL. New evidence that a large proportion of human blood plasma cell-free DNA is localized in exosomes. PLoS One 2017;12:e0183915.

41. Wang W, Kong P, Ma G, Li L, Zhu J, Xia T, et al. Characterization of the release and biological significance of cell-free DNA from breast cancer cell lines. Oncotarget 2017;8:43180-91.

42. Bronkhorst AJ, Wentzel JF, Aucamp J, van DE, du PL, Pretorius PJ. Characterization of the cell-free DNA released by cultured cancer cells. Biochim Biophys Acta 2015;1863:157-65.

43. Toth K, Patai AV, Kalmar A, Bartak BK, Nagy ZB, Galamb O, et al. Circadian rhythm of methylated septin 9, cell-free DNA amount and tumor markers in colorectal cancer patients. Pathol Oncol Res 2017;23:699-706.

44. Rasmussen L, Herzog M, Romer E, Micallef J, Bulut O, Wilhelmsen $M$, et al. Pre-analytical variables of circulating cell-free nucleosomes containing 5-methylcytosine DNA or histone modification H3K9Me3. Scand J Clin Lab Invest 2016;76:448-53.

45. Streleckiene G, Reid HM, Arnold N, Bauerschlag D, Forster M. Quantifying cell free DNA in urine: comparison between commercial kits, impact of gender and inter-individual variation. Biotechniques 2018;64:225-30.

46. Garcia-Olmo DC, Picazo MG, Toboso I, Asensio Al, Garcia-Olmo D. Quantitation of cell-free DNA and RNA in plasma during tumor progression in rats. Mol Cancer 2013;12:8.

47. Gasparello J, Allegretti M, Tremante E, Fabbri E, Amoreo CA, Romania $\mathrm{P}$, et al. Liquid biopsy in mice bearing colorectal carcinoma xenografts: gateways regulating the levels of circulating tumor DNA (ctDNA) and miRNA (ctmiRNA). J Exp Clin Cancer Res 2018;37:124.

48. Tsumita T, Iwanaga M. Fate of injected deoxyribonucleic acid in mice. Nature 1963;198:1088-9.

49. Gauthier VJ, Tyler LN, Mannik M. Blood clearance kinetics and liver uptake of mononucleosomes in mice. J Immunol 1996;156:1151-6.

50. Chused TM, Steinberg AD, Talal N. The clearance and localization of nucleic acids by New Zealand and normal mice. Clin Exp Immunol 1972;12:465-76.

51. Emlen W, Mannik M. Effect of DNA size and strandedness on the in vivo clearance and organ localization of DNA. Clin Exp Immunol 1984;56:185-92.

52. Du Clos TW, Volzer MA, Hahn FF, Xiao R, Mold C, Searles RP. Chromatin clearance in $\mathrm{C} 57 \mathrm{Bl} / 10$ mice: interaction with heparan sulphate proteoglycans and receptors on Kupffer cells. Clin Exp Immunol 1999;117:403-11.

53. Lo YM, Zhang J, Leung TN, Lau TK, Chang AM, Hjelm NM. Rapid clearance of fetal DNA from maternal plasma. Am J Hum Genet 1999;64:218-24.

54. Botezatu I, Serdyuk O, Potapova G, Shelepov V, Alechina R, Molyaka $Y$, et al. Genetic analysis of DNA excreted in urine: a new approach for detecting specific genomic DNA sequences from cells dying in an organism. Clin Chem 2000;46:1078-84.

55. Lo YM, Leung SF, Chan LY, Chan AT, Lo KW, Johnson PJ, et al. Kinetics of plasma Epstein-Barr virus DNA during radiation therapy for nasopharyngeal carcinoma. Cancer Res 2000;60:2351-55.

56. To EW, Chan KC, Leung SF, Chan LY, To KF, Chan AT, et al. Rapid clearance of plasma Epstein-Barr virus DNA after surgical treatment of nasopharyngeal carcinoma. Clin Cancer Res 2003;9:3254-9.

57. Zhong XY, Hahn D, Troeger C, Klemm A, Stein G, Thomson P, et al. Cell-free DNA in urine: a marker for kidney graft rejection, but not for prenatal diagnosis? Ann N Y Acad Sci 2001;945:250-7.
58. García Moreira V, de la Cera Martínez T, Gago González E, Prieto García B, Alvarez Menéndez FV. Increase in and clearance of cellfree plasma DNA in hemodialysis quantified by real-time PCR GARCIA2006. Clin Chem Lab Med 2006;44:1410-5.

59. Kasai M, Francesconi A, Petraitiene R, Petraitis V, Kelaher AM, Kim HS, et al. Use of quantitative real-time PCR to study the kinetics of extracellular DNA released from Candida albicans, with implications for diagnosis of invasive Candidiasis. J Clin Microbiol 2006;44:143-50.

60. Tamkovich SN, Cherepanova AV, Kolesnikova EV, Rykova EY, Pyshnyi DV, Vlassov VV, et al. Circulating DNA and DNase activity in human blood. Ann N Y Acad Sci 2006;1075:191-6.

61. Diehl F, Schmidt K, Choti MA, Romans K, Goodman S, Li M, et al. Circulating mutant DNA to assess tumor dynamics. Nat Med 2008;14:985-90.

62. Yu SC, Lee SW, Jiang P, Leung TY, Chan KC, Chiu RW, et al. High-resolution profiling of fetal DNA clearance from maternal plasma by massively parallel sequencing. Clin Chem 2013;59:1228-37.

63. Yao W, Mei C, Nan X, Hui L. Evaluation and comparison of in vitro degradation kinetics of DNA in serum, urine and saliva: a qualitative study. Gene 2016;590:142-8.

64. Muhanna N, Di Grappa MA, Chan HH, Khan T, Jin CS, Zheng Y, et al. Cell-free DNA kinetics in a pre-clinical model of head and neck cancer. Sci Rep 2017;7:16723.

65. Wilson IJ, Burchell RK, Worth AJ, Burton SE, Gedye KR, Clark KJ, et al. Kinetics of plasma cell-free DNA and creatine kinase in a canine model of tissue injury. J Vet Intern Med 2018;32:157-64.

66. Bose S, Deininger M, Gora-Tybor J, Goldman JM, Melo JV. The presence of typical and atypical BCR-ABL fusion genes in leukocytes of normal individuals: biologic significance and implications for the assessment of minimal residual disease. Blood 1998;92:3362-7.

67. Liu Y, Hernandez AM, Shibata D, Cortopassi GA. BCL2 translocation frequency rises with age in humans. Proc Natl Acad Sci U S A 1994;91:8910-4.

68. Limpens J, Stad R, Vos C, de VC, de JD, van Ommen GJ, et al. Lymphoma-associated translocation $\mathrm{t}(14 ; 18)$ in blood $\mathrm{B}$ cells of normal individuals. Blood 1995;85:2528-36.

69. Sikkink SK, Liloglou T, Maloney P, Gosney JR, Field JK. Indepth analysis of molecular alterations within normal and tumour tissue from an entire bronchial tree. Int I Oncol 2003;22:589-95.

70. Gormally E, Vineis P, Matullo G, Veglia F, Caboux E, Le RE, et al. TP53 and KRAS2 mutations in plasma DNA of healthy subjects and subsequent cancer occurrence: a prospective study. Cancer Res 2006;66:6871-6.

71. Fernandez-Cuesta L, Perdomo S, Avogbe PH, Leblay N, Delhomme TM, Gaborieau V, et al. Identification of circulating tumor DNA for the early detection of small-cell lung cancer. EBioMedicine 2016;10:117-23.

72. Allenson K, Castillo J, San Lucas FA, Scelo G, Kim DU, Bernard V, et al. High prevalence of mutant KRAS in circulating exosomederived DNA from early-stage pancreatic cancer patients. Ann Oncol 2017;28:741-7.

73. Krimmel JD, Schmitt MW, Harrell MI, Agnew KJ, Kennedy SR, Emond MJ, et al. Ultra-deep sequencing detects ovarian cancer cells in peritoneal fluid and reveals somatic TP53 mutations in noncancerous tissues. Proc Natl Acad Sci U S A 2016;113:6005-10.

74. Genovese G, Kahler AK, Handsaker RE, Lindberg J, Rose SA, Bakhoum SF, et al. Clonal hematopoiesis and blood- 
cancer risk inferred from blood DNA sequence. N Engl J Med 2014;371:2477-87.

75. Wang JF, Pu X, Zhang X, Chen K, Xi Y, Wang J, et al. Variants with a low allele frequency detected in genomic DNA affect the accuracy of mutation detection in cell-free DNA by next-generation sequencing. Cancer 2018;124:1061-9.

76. Martincorena I, Roshan A, Gerstung M, Ellis P, Van LP, McLaren $\mathrm{S}$, et al. Tumor evolution. High burden and pervasive positive selection of somatic mutations in normal human skin. Science 2015;348:880-6.

77. Martincorena I, Fowler JC, Wabik A, Lawson AR, Abascal F, Hall MW, et al. Somatic mutant clones colonize the human esophagus with age. Science 2018;362:911-7.

78. Martincorena I. Somatic mutation and clonal expansions in human tissues. Genome Med 2019;11:35.

79. Chiu RW, Poon LL, Lau TK, Leung TN, Wong EM, Lo YM. Effects of blood-processing protocols on fetal and total DNA quantification in maternal plasma. Clin Chem 2001;47:1607-13.

80. Lui YY, Chik KW, Chiu RW, Ho CY, Lam CW, Lo YM. Predominant hematopoietic origin of cell-free DNA in plasma and serum after sex-mismatched bone marrow transplantation. Clin Chem 2002;48:421-7.

81. Swinkels DW, Wiegerinck E, Steegers EA, de Kok JB. Effects of blood-processing protocols on cell-free DNA quantification in plasma. Clin Chem 2003;49:525-6.

82. Herrera LJ, Raja S, Gooding WE, El-Hefnawy T, Kelly L, Luketich JD, et al. Quantitative analysis of circulating plasma DNA as a tumor marker in thoracic malignancies. Clin Chem 2005;51:113-8.

83. Page K, Powles T, Slade MJ, DE Bella MT, Walker RA, Coombes $\mathrm{RC}$, et al. The importance of careful blood processing in isolation of cell-free DNA. Ann N Y Acad Sci 2006;1075:313-7.

84. Page K, Guttery DS, Zahra N, Primrose L, Elshaw SR, Pringle JH, et al. Influence of plasma processing on recovery and analysis of circulating nucleic acids. PLoS One 2013;8:e77963.

85. Sherwood JL, Corcoran C, Brown H, Sharpe AD, Musilova M, Kohlmann A. Optimised pre-analytical methods improve KRAS mutation detection in circulating tumour DNA (ctDNA) from patients with nonsmall cell lung cancer (NSCLC). PLoS One 2016;11:e0150197.

86. van Ginkel JH, Slieker FJ, de BR, van Es RJ, Van Cann EM, Willems SM. Cell-free nucleic acids in body fluids as biomarkers for the prediction and early detection of recurrent head and neck cancer: a systematic review of the literature. Oral Oncol 2017;75:8-15.

87. Risberg B, Tsui DW, Biggs H, de Almagro AR, Dawson SJ, Hodgkin $C$, et al. Effects of collection and processing procedures on plasma circulating cell-free DNA from cancer patients. J Mol Diagn 2018;20:883-92.

88. Sorber L, Zwaenepoel K, Jacobs J, De WK, Goethals S, Reclusa $P$, et al. A multicenter study to assess EGFR mutational status in plasma: focus on an optimized workflow for liquid biopsy in a clinical setting. Cancers (Basel) 2018;10:290.

89. Anker P, Stroun M, Maurice PA. Spontaneous release of DNA by human blood lymphoctyes as shown in an in vitro system. Cancer Res 1975;35:2375-82.

90. Lee TH, Montalvo L, Chrebtow V, Busch MP. Quantitation of genomic DNA in plasma and serum samples: higher concentrations of genomic DNA found in serum than in plasma. Transfusion 2001;41:276-82.

91. Lam NY, Rainer TH, Chiu RW, Lo YM. EDTA is a better anticoagulant than heparin or citrate for delayed blood processing for plasma DNA analysis. Clin Chem 2004;50:256-7.
92. Barra GB, Santa Rita TH, de Almeida Vasques J, Chianca CF, Nery LF, Santana Soares CS. EDTA-mediated inhibition of DNases protects circulating cell-free DNA from ex vivo degradation in blood samples. Clin Biochem 2015;48:976-81.

93. Sato A, Nakashima C, Abe T, Kato J, Hirai M, Nakamura T, et al. Investigation of appropriate pre-analytical procedure for circulating free DNA from liquid biopsy. Oncotarget 2018;9:31904-14.

94. Fernando MR, Chen K, Norton S, Krzyzanowski G, Bourne D, Hunsley B, et al. A new methodology to preserve the original proportion and integrity of cell-free fetal DNA in maternal plasma during sample processing and storage. Prenat Diagn 2010;30:418-24.

95. Hidestrand M, Stokowski R, Song K, Oliphant A, Deavers J, Goetsch $M$, et al. Influence of temperature during transportation on cell-free DNA analysis. Fetal Diagn Ther 2012;31:122-8.

96. Kadam SK, Farmen M, Brandt JT. Quantitative measurement of cell-free plasma DNA and applications for detecting tumor genetic variation and promoter methylation in a clinical setting. J Mol Diagn 2012;14:346-56.

97. Norton SE, Luna KK, Lechner JM, Qin J, Fernando MR. A new blood collection device minimizes cellular DNA release during sample storage and shipping when compared to a standard device. J Clin Lab Anal 2013;27:305-11.

98. Wong D, Moturi S, Angkachatchai V, Mueller R, DeSantis G, van den Boom D, et al. Optimizing blood collection, transport and storage conditions for cell free DNA increases access to prenatal testing. Clin Biochem 2013;46:1099-104.

99. Toro PV, Erlanger B, Beaver JA, Cochran RL, VanDenBerg DA, Yakim E, et al. Comparison of cell stabilizing blood collection tubes for circulating plasma tumor DNA. Clin Biochem 2015;48:993-8.

100. Wang Q, Cai Y, Brady P, Vermeesch JR. Real-time PCR evaluation of cell-free DNA subjected to various storage and shipping conditions. Genet Mol Res 2015;14:12797-804.

101. Denis MG, Knol AC, Theoleyre S, Vallee A, Dreno B. Efficient detection of BRAF mutation in plasma of patients after longterm storage of blood in cell-free DNA blood collection Tubes. Clin Chem 2015;61:886-8.

102. Kang Q, Henry NL, Paoletti C, Jiang H, Vats P, Chinnaiyan AM, et al. Comparative analysis of circulating tumor DNA stability In K3EDTA, Streck, and CellSave blood collection tubes. Clin Biochem 2016;49:1354-60.

103. Diaz IM, Nocon A, Mehnert DH, Fredebohm J, Diehl F, Holtrup F. Performance of streck cfDNA blood collection tubes for liquid biopsy testing. PLoS One 2016;11:e0166354.

104. Henao DE, Yachnin J, Gronberg H, Lindberg J. The in vitro stability of circulating tumour DNA. PLoS One 2016;11:e0168153.

105. Ahlborn LB, Madsen M, Jonson L, Nielsen FC, Lassen U, Yde CW, et al. Concordance of mutation detection in circulating tumor DNA in early clinical trials using different blood collection protocols. Clin Lab 2017;63:1755-9.

106. Warton K, Yuwono NL, Cowley MJ, McCabe MJ, So A, Ford CE. Evaluation of streck BCT and PAXgene stabilised blood collection tubes for cell-free circulating DNA studies in plasma. Mol Diagn Ther 2017;21:563-70.

107. Parpart-Li S, Bartlett B, Popoli M, Adleff V, Tucker L, Steinberg $R$, et al. The effect of preservative and temperature on the analysis of circulating tumor DNA. Clin Cancer Res 2017;23:2471-7. 108. Mehrotra M, Singh RR, Chen W, Huang RS, Almohammedsalim AA, Barkoh BA, et al. Study of preanalytic and analytic vari- 
ables for clinical next-generation sequencing of circulating cell-free nucleic acid. J Mol Diagn 2017;19:514-24.

109. Alidousty C, Brandes D, Heydt C, Wagener S, Wittersheim M, Schafer SC, et al. Comparison of blood collection tubes from three different manufacturers for the collection of cell-free DNA for liquid biopsy mutation testing. J Mol Diagn 2017;19:801-4.

110. van Dessel LF, Beije N, Helmijr JC, Vitale SR, Kraan J, Look MP, et al. Application of circulating tumor DNA in prospective clinical oncology trials - standardization of preanalytical conditions. Mol Oncol 2017;11:295-304.

111. van Ginkel JH, van den Broek DA, van KJ, Linders D, de WR, Willems SM, et al. Preanalytical blood sample workup for cell-free DNA analysis using droplet digital PCR for future molecular cancer diagnostics. Cancer Med 2017;6:2297-307.

112. Schmidt B, Reinicke D, Reindl I, Bork I, Wollschlager B, Lambrecht $\mathrm{N}$, et al. Liquid biopsy - performance of the PAXgene(R) blood ccfDNA tubes for the isolation and characterization of cell-free plasma DNA from tumor patients. Clin Chim Acta 2017;469:94-8.

113. Wollison BM, Thai E, Mckinney A, Ward A, Clapp A, Clinton $C$, et al. Blood collection in cell-stabilizing tubes does not impact germline DNA quality for pediatric patients. PLoS One 2017;12:e0188835.

114. Nikolaev S, Lemmens L, Koessler T, Blouin JL, Nouspikel T. Circulating tumoral DNA: preanalytical validation and quality control in a diagnostic laboratory. Anal Biochem 2018;542:34-9.

115. Bartak BK, Kalmar A, Galamb O, Wichmann B, Nagy ZB, Tulassay Z, et al. Blood Collection and cell-free DNA isolation methods influence the sensitivity of liquid biopsy analysis for colorectal cancer detection. Pathol Oncol Res 2019;25:915-23.

116. Zhao Y, Li Y, Chen P, Li S, Luo J, Xia H. Performance comparison of blood collection tubes as liquid biopsy storage system for minimizing cfDNA contamination from genomic DNA. J Clin Lab Anal 2019;33:e22670.

117. Enko D, Halwachs-Baumann G, Kriegshauser G. Plasma free DNA: evaluation of temperature-associated storage effects observed for Roche Cell-Free DNA collection tubes. Biochem Med (Zagreb) 2019;29:010904.

118. Ward GA, Lenhardt J, Witte T, Keitel D, Kaufhold A, Maass KK, et al. Evaluation of storage tubes for combined analysis of circulating nucleic acids in liquid biopsies. Int J Mol Sci 2019;20:704.

119. Murugesan K, Hogan CA, Palmer Z, Reeve B, Theron G, Andama $A$, et al. Investigation of preanalytical variables impacting pathogen cell-free DNA in blood and urine. J Clin Microbiol 2019;57:e00782-19.

120. Das K, Fernando MR, Basiaga S, Wigginton SM, Williams T. Effects of a novel cell stabilizing reagent on DNA amplification by PCR as compared to traditional stabilizing reagents. Acta Histochem 2014;116:55-60.

121. Jung M, Klotzek S, Lewandowski M, Fleischhacker M, Jung K. Changes in concentration of DNA in serum and plasma during storage of blood samples. Clin Chem 2003;49:1028-9.

122. Angert RM, LeShane ES, Lo YM, Chan LY, Delli-Bovi LC, Bianchi DW. Fetal cell-free plasma DNA concentrations in maternal blood are stable 24 hours after collection: analysis of first- and third-trimester samples. Clin Chem 2003;49:195-8.

123. Chan KC, Yeung SW, Lui WB, Rainer TH, Lo YM. Effects of preanalytical factors on the molecular size of cell-free DNA in blood. Clin Chem 2005;51:781-4.

124. Finning K, Martin P, Summers J, Massey E, Poole G, Daniels G. Effect of high throughput RHD typing of fetal DNA in maternal plasma on use of anti-RhD immunoglobulin in RhD negative pregnant women: prospective feasibility study. Br Med J 2008;336:816-8.

125. Xue X, Teare MD, Holen I, Zhu YM, Woll PJ. Optimizing the yield and utility of circulating cell-free DNA from plasma and serum. Clin Chim Acta 2009;404:100-4.

126. Muller SP, Bartels I, Stein W, Emons G, Gutensohn K, Legler TJ. Cell-free fetal DNA in specimen from pregnant women is stable up to 5 days. Prenat Diagn 2011;31:1300-4.

127. Buysse K, Beulen L, Gomes I, Gilissen C, Keesmaat C, Janssen $I M$, et al. Reliable noninvasive prenatal testing by massively parallel sequencing of circulating cell-free DNA from maternal plasma processed up to $24 \mathrm{~h}$ after venipuncture. Clin Biochem 2013;46:1783-6.

128. Clausen FB, Jakobsen TR, Rieneck K, Krog GR, Nielsen LK, Tabor $A$, et al. Pre-analytical conditions in non-invasive prenatal testing of cell-free fetal RHD. PLoS One 2013;8:e76990.

129. Ordonez E, Rueda L, Canadas MP, Fuster C, Cirigliano V. Evaluation of sample stability and automated DNA extraction for fetal sex determination using cell-free fetal DNA in maternal plasma. Biomed Res Int 2013;2013:195363.

130. Garcia J, Dusserre E, Cheynet V, Bringuier PP, Brengle-Pesce $\mathrm{K}$, Wozny AS, et al. Evaluation of pre-analytical conditions and comparison of the performance of several digital PCR assays for the detection of major EGFR mutations in circulating DNA from non-small cell lung cancers: the CIRCAN_0 study. Oncotarget 2017;8:87980-96.

131. Guo Q, Wang J, Xiao J, Wang L, Hu X, Yu W, et al. Heterogeneous mutation pattern in tumor tissue and circulating tumor DNA warrants parallel NGS panel testing. Mol Cancer 2018;17:131.

132. Di MA, Bartlett J, Cheng Y, Pasic MD, Yousef GM. Liquid biopsy: a step forward towards precision medicine in urologic malignancies. Mol Cancer 2017;16:80.

133. Siravegna G, Marsoni S, Siena S, Bardelli A. Integrating liquid biopsies into the management of cancer. Nat Rev Clin Oncol 2017;14:531-48.

134. Stockley T, Souza CA, Cheema PK, Melosky B, Kamel-Reid S, Tsao MS, et al. Evidence-based best practices for EGFR T790M testing in lung cancer in Canada. Curr Oncol 2018;25:163-9.

135. Simundic AM, Bolenius K, Cadamuro J, Church S, Cornes MP, van Dongen-Lases EC, et al. Joint EFLM-COLABIOCLI Recommendation for venous blood sampling. Clin Chem Lab Med 2018;56:2015-38.

136. Mouser A, Uettwiller-Geiger D, Plokhoy E, Berube J, Ahuja AJ, Stankovic AK. Evaluation of pain and specimen quality by use of a novel 25-gauge blood collection set with ultrathin wall cannula and 5-bevel tip design. J Appl Lab Med 2017;2:201-10.

137. Kopreski MS, Benko FA, Kwee C, Leitzel KE, Eskander E, Lipton $A$, et al. Detection of mutant K-ras DNA in plasma or serum of patients with colorectal cancer. Br J Cancer 1997;76:1293-9.

138. Kopreski MS, Benko FA, Kwak LW, Gocke CD. Detection of tumor messenger RNA in the serum of patients with malignant melanoma. Clin Cancer Res 1999;5:1961-5.

139. Lee T, LeShane ES, Messerlian GM, Canick JA, Farina A, Heber WW, et al. Down syndrome and cell-free fetal DNA in archived maternal serum. Am J Obstet Gynecol 2002;187:1217-1.

140. Sozzi G, Roz L, Conte D, Mariani L, Andriani F, Verderio P, et al. Effects of prolonged storage of whole plasma or isolated plasma DNA on the results of circulating DNA quantification assays. J Natl Cancer Inst 2005;97:1848-50. 
141. Koide K, Sekizawa A, Iwasaki M, Matsuoka R, Honma S, Farina $A$, et al. Fragmentation of cell-free fetal DNA in plasma and urine of pregnant women. Prenat Diagn 2005;25:604-7.

142. Holdenrieder S, von PJ, Nagel D, Stieber P. Long-term stability of circulating nucleosomes in serum. Anticancer Res 2010;30:1613-5.

143. Grasedieck S, Scholer N, Bommer M, Niess JH, Tumani H, Rouhi $A$, et al. Impact of serum storage conditions on microRNA stability. Leukemia 2012;26:2414-6.

144. El Messaoudi S, Rolet F, Mouliere F, Thierry AR. Circulating cell free DNA: Preanalytical considerations. Clin Chim Acta 2013;424:222-30.

145. Pinzani P, Salvianti F, Orlando C, Pazzagli M. Circulating cellfree DNA in cancer. Methods Mol Biol 2014;1160:133-45.

146. Barrett AN, Thadani HA, Laureano-Asibal C, Ponnusamy S, Choolani M. Stability of cell-free DNA from maternal plasma isolated following a single centrifugation step. Prenat Diagn 2014;34:1283-8.

147. Zavridou M, Mastoraki S, Strati A, Tzanikou E, Chimonidou M, Lianidou E. Evaluation of preanalytical conditions and implementation of quality control steps for reliable gene expression and DNA methylation analyses in liquid biopsies. Clin Chem 2018;64:1522-33.

148. Shishido SN, Welter L, Rodriguez-Lee M, Kolatkar A, Xu L, Ruiz $C$, et al. Preanalytical variables for the genomic assessment of the cellular and acellular fractions of the liquid biopsy in a cohort of breast cancer patients. J Mol Diagn 2020;22:319.

149. Heider K, Wan JC, Hall J, Boyle S, Hudecova I, Gale D, et al. Detection of ctDNA from dried blood spots after DNA size selection. bioRxiv 2019. Available at: https://doi. org/10.1101/759365.

150. Chang CP, Chia RH, Wu TL, Tsao KC, Sun CF, Wu JT. Elevated cellfree serum DNA detected in patients with myocardial infarction. Clin Chim Acta 2003;327:95-101.

151. O'Connell GC, Petrone AB, Tennant CS, Lucke-Wold N, Kabbani Y, Tarabishy AR, et al. Circulating extracellular DNA levels are acutely elevated in ischaemic stroke and associated with innate immune system activation. Brain Inj 2017;31:1369-75.

152. Lo YM, Rainer TH, Chan LY, Hjelm NM, Cocks RA. Plasma DNA as a prognostic marker in trauma patients. Clin Chem 2000;46:319-23.

153. Tug S, Helmig S, Deichmann ER, Schmeier-Jurchott A, Wagner $\mathrm{E}$, Zimmermann T, et al. Exercise-induced increases in cell free DNA in human plasma originate predominantly from cells of the haematopoietic lineage. Exerc Immunol Rev 2015;21:164-73.

154. Fleischhacker M, Schmidt B. Circulating nucleic acids (CNAs) and cancer-a survey. Biochim Biophys Acta 2007;1775:181-232.

155. Bronkhorst AJ, Ungerer V, Holdenrieder S. Comparison of methods for the quantification of cell-free DNA isolated from cell culture supernatant. Tumour Biol 2019;41:1010428319866369.

156. Giacona MB, Ruben GC, Iczkowski KA, Roos TB, Porter DM, Sorenson GD. Cell-free DNA in human blood plasma: length measurements in patients with pancreatic cancer and healthy controls. Pancreas 1998;17:89-97.

157. Underhill HR, Kitzman JO, Hellwig S, Welker NC, Daza R, Baker DN, et al. Fragment length of circulating tumor DNA. PLoS Genet 2016;12:e1006162.

158. Mouliere F, Robert B, Arnau PE, Del RM, Ychou M, Molina F, et al. High fragmentation characterizes tumour-derived circulating DNA. PLoS One 2011;6:e23418.
159. Diehl F, Li M, Dressman D, He Y, Shen D, Szabo S, et al. Detection and quantification of mutations in the plasma of patients with colorectal tumors. Proc Natl Acad Sci U S A 2005;102:16368-73.

160. Nakashima C, Sato A, Abe T, Kato J, Hirai M, Nakamura T, et al. Automated DNA extraction using cellulose magnetic beads can improve EGFR point mutation detection with liquid biopsy by efficiently recovering short and long DNA fragments. Oncotarget 2018;9:25181-92.

161. Jiang P, Lo YM. The long and short of circulating cell-free DNA and the ins and outs of molecular diagnostics. Trends Genet 2016;32:360.

162. Vagner T, Spinelli C, Minciacchi VR, Balaj L, Zandian M, Conley $A$, et al. Large extracellular vesicles carry most of the tumour DNA circulating in prostate cancer patient plasma. J Extracell Vesicles 2018;7:1505403.

163. Sriram KB, Relan V, Clarke BE, Duhig EE, Windsor MN, Matar KS, et al. Pleural fluid cell-free DNA integrity index to identify cytologically negative malignant pleural effusions including mesotheliomas. BMC Cancer 2012;12:428.

164. Wang BG, Huang HY, Chen YC, Bristow RE, Kassauei K, Cheng $\mathrm{CC}$, et al. Increased plasma DNA integrity in cancer patients. Cancer Res 2003;63:3966-8.

165. Kamel AM, Teama S, Fawzy A, El DM. Plasma DNA integrity index as a potential molecular diagnostic marker for breast cancer. Tumour Biol 2016;37:7565-72.

166. Ramachandran K, Speer CG, Fiddy S, Reis IM, Singal R. Free circulating DNA as a biomarker of prostate cancer: comparison of quantitation methods. Anticancer Res 2013;33:4521-9.

167. Szpechcinski A, Struniawska R, Zaleska J, Chabowski M, Orlowski T, Roszkowski K, et al. Evaluation of fluorescencebased methods for total vs. amplifiable DNA quantification in plasma of lung cancer patients. J Physiol Pharmacol 2008;59 Suppl 6:675-81.

168. Lu T, Li J. Clinical applications of urinary cell-free DNA in cancer: current insights and promising future. Am J Cancer Res 2017;7:2318-32.

169. Su Y, Fang H, Jiang F. Integrating DNA methylation and microRNA biomarkers in sputum for lung cancer detection. Clin Epigenetics 2016;8:109.

170. Wu Z, Yang Z, Li CS, Zhao W, Liang ZX, Dai Y, et al. Differences in the genomic profiles of cell-free DNA between plasma, sputum, urine, and tumor tissue in advanced NSCLC. Cancer Med 2019;8:910-9.

171. Lacedonia D, Palladino GP, Foschino-Barbaro MP, Scioscia G, Carpagnano GE. Expression profiling of miRNA-145 and miRNA-338 in serum and sputum of patients with COPD, asthma, and asthma-COPD overlap syndrome phenotype. Int J Chron Obstruct Pulmon Dis 2017;12:1811-7.

172. Guo Z, Xie Z, Shi H, Du W, Peng L, Han W, et al. Malignant pleural effusion supernatant is an alternative liquid biopsy specimen for comprehensive mutational profiling. Thorac Cancer 2019;10:823-31.

173. Zhou S, Xu B, Qi L, Zhu D, Liu B, Wei J. Next-generation sequencing reveals mutational accordance between cell-free DNA from plasma, malignant pleural effusion and ascites and directs targeted therapy in a gastric cancer patient. Cancer Biol Ther 2019;20:15-20. 
174. Wong FC, Sun K, Jiang P, Cheng YK, Chan KC, Leung TY, et al. Cell-free DNA in maternal plasma and serum: a comparison of quantity, quality and tissue origin using genomic and epigenomic approaches. Clin Biochem 2016;49:1379.

175. Thijssen MA, Swinkels DW, Ruers TJ, de Kok JB. Difference between free circulating plasma and serum DNA in patients with colorectal liver metastases. Anticancer Res 2002;22:421-5.

176. Vallee A, Marcq M, Bizieux A, Kouri CE, Lacroix H, Bennouna J, et al. Plasma is a better source of tumor-derived circulating cell-free DNA than serum for the detection of EGFR alterations in lung tumor patients. Lung Cancer 2013;82:373-4.

177. Thierry AR, Mouliere F, Gongora C, Ollier J, Robert B, Ychou $M$, et al. Origin and quantification of circulating DNA in mice with human colorectal cancer xenografts. Nucleic Acids Res 2010;38:6159-75.

178. Kobayashi K, Naoki K, Manabe T, Masuzawa K, Hasegawa H, Yasuda $\mathrm{H}$, et al. Comparison of detection methods of EGFR T790M mutations using plasma, serum, and tumor tissue in EGFR-TKI-resistant non-small cell lung cancer. Onco Targets Ther 2018;11:3335-43.

179. Mayo-de-Las-Casas C, Jordana-Ariza N, Garzon-Ibanez M, Balada-Bel A, Bertran-Alamillo J, Viteri-Ramirez S, et al. Large scale, prospective screening of EGFR mutations in the blood of advanced NSCLC patients to guide treatment decisions. Ann Oncol 2017;28:2248-55.

180. Aung KL, Donald E, Ellison G, Bujac S, Fletcher L, Cantarini $M$, et al. Analytical validation of BRAF mutation testing from circulating free DNA using the amplification refractory mutation testing system. J Mol Diagn 2014;16:343-9.

181. Boeckx N, Op de BK, Beyens M, Deschoolmeester V, Hermans $\mathrm{C}$, De CP, et al. Mutation and methylation analysis of circulating tumor DNA can be used for follow-up of metastatic colorectal cancer patients. Clin Colorectal Cancer 2018;17:e369-79.

182. Lucchetti D, Fattorossi A, Sgambato A. Extracellular vesicles in oncology: progress and pitfalls in the methods of isolation and analysis. Biotechnol J 2019;14:e1700716.

183. Pan W, Gu W, Nagpal S, Gephart MH, Quake SR. Brain tumor mutations detected in cerebral spinal fluid. Clin Chem 2015;61:514-22.

184. Pentsova El, Shah RH, Tang J, Boire A, You D, Briggs S, et al. Evaluating cancer of the central nervous system through next-generation sequencing of cerebrospinal fluid. J Clin Oncol 2016;34:2404-15.

185. Rhodes CH, Honsinger C, Sorenson GD. Detection of tumorderived DNA in cerebrospinal fluid. J Neuropathol Exp Neurol 1994;53:364-8.

186. De Mattos-Arruda L, Mayor R, Ng CK, Weigelt B, MartinezRicarte F, Torrejon D, et al. Cerebrospinal fluid-derived circulating tumour DNA better represents the genomic alterations of brain tumours than plasma. Nat Commun 2015;6:8839.

187. Mouliere F, Mair R, Chandrananda D, Marass F, Smith CG, Su J, et al. Detection of cell-free DNA fragmentation and copy number alterations in cerebrospinal fluid from glioma patients. EMBO Mol Med 2018;10:e9323.

188. Ge M, Zhan Q, Zhang Z, Ji X, Zhou X, Huang R, et al. Different nextgeneration sequencing pipelines based detection of tumor DNA in cerebrospinal fluid of lung adenocarcinoma cancer patients with leptomeningeal metastases. BMC Cancer 2019;19:143.

189. Shekhtman EM, Anne K, Melkonyan HS, Robbins DJ, Warsof SL, Umansky SR. Optimization of transrenal DNA analysis: detection of fetal DNA in maternal urine. Clin Chem 2009;55:723-29.
190. Bosschieter J, Bach S, Bijnsdorp IV, Segerink LI, Rurup WF, van Splunter AP, et al. A protocol for urine collection and storage prior to DNA methylation analysis. PLoS One 2018;13:e0200906.

191. Li P, Ning J, Luo X, Du H, Zhang Q, Zhou G, et al. New method to preserve the original proportion and integrity of urinary cellfree DNA. J Clin Lab Anal 2019;33:e22668.

192. Malentacchi F, Pizzamiglio S, Verderio P, Pazzagli M, Orlando C, Ciniselli CM, et al. Influence of storage conditions and extraction methods on the quantity and quality of circulating cell-free DNA (ccfDNA): the SPIDIA-DNAplas External Quality Assessment experience. Clin Chem Lab Med 2015;53:1935-42.

193. Devonshire AS, Whale AS, Gutteridge A, Jones G, Cowen S, Foy CA, et al. Towards standardisation of cell-free DNA measurement in plasma: controls for extraction efficiency, fragment size bias and quantification. Anal Bioanal Chem 2014;406:6499-512.

194. Diefenbach RJ, Lee JH, Kefford RF, Rizos H. Evaluation of commercial kits for purification of circulating free DNA. Cancer Genet 2018;228-229:21-7.

195. Warton K, Graham LJ, Yuwono N, Samimi G. Comparison of 4 commercial kits for the extraction of circulating DNA from plasma. Cancer Genet 2018;228-229:143-50.

196. Liu Z, Yang X, Chen H, Zhu S, Zeng J, Chen F, et al. Evaluation of five cell-free DNA isolation kits for plasma. bioRxiv 2019. Available at: https://doi.org/10.1101/715821.

197. Sisson BA, Uvalic J, Kelly K, Selvam P, Hesse AN, Ananda G, et al. Technical and regulatory considerations for taking liquid biopsy to the clinic: validation of the JAX plasmamonitor (TM) assay. Biomark Insights 2019;14:1177271919826545.

198. O'Connell GC, Chantler PD, Barr TL. High interspecimen variability in nucleic acid extraction efficiency necessitates the use of spike-in control for accurate qPCR-based measurement of plasma cell-free DNA levels. Lab Med 2017;48:332-8.

199. Sorber L, Zwaenepoel K, Deschoolmeester V, Roeyen G, Lardon F, Rolfo C, et al. A Comparison of cell-free DNA isolation kits: isolation and quantification of cell-free DNA in plasma. J Mol Diagn 2017;19:162-8.

200. Cook L, Starr K, Boonyaratanakornkit J, Hayden R, Sam SS, Caliendo AM. Does size matter? Comparison of extraction yields for different-sized DNA fragments by seven different routine and four new circulating cell-free extraction methods. J Clin Microbiol 2018;56:e01061.

201. Perez-Barrios C, Nieto-Alcolado I, Torrente M, Jimenez-Sanchez C, Calvo V, Gutierrez-Sanz L, et al. Comparison of methods for circulating cell-free DNA isolation using blood from cancer patients: impact on biomarker testing. Transl Lung Cancer Res 2016;5:665-72.

202. Fong SL, Zhang JT, Lim CK, Eu KW, Liu Y. Comparison of 7 methods for extracting cell-free DNA from serum samples of colorectal cancer patients. Clin Chem 2009;55:587-9.

203. Mazurek AM, Fiszer-Kierzkowska A, Rutkowski T, Skladowski K, Pierzyna M, Scieglinska D, et al. Optimization of circulating cell-free DNA recovery for KRAS mutation and HPV detection in plasma. Cancer Biomark 2013;13:385-94.

204. Pandoh PK, Corbett RD, McDonald H, Alcaide M, Kirk H, Trinh $\mathrm{E}$, et al. A high-throughput protocol for isolating cell-free circulating tumor DNA from peripheral blood. Biotechniques 2019;66:85-92.

205. Haselmann V, Ahmad-Nejad P, Geilenkeuser WJ, Duda A, Gabor M, Eichner R, et al. Results of the first external quality 
assessment scheme (EQA) for isolation and analysis of circulating tumour DNA (ctDNA). Clin Chem Lab Med 2018;56:220-8.

206. Fassunke J, Ihle MA, Lenze D, Lehmann A, Hummel M, Vollbrecht C, et al. EGFR T790M mutation testing of non-small cell lung cancer tissue and blood samples artificially spiked with circulating cell-free tumor DNA: results of a round robin trial. Virchows Arch 2017;471:509-20.

207. Keppens C, Dequeker EM, Patton SJ, Normanno N, Fenizia F, Butler R, et al. International pilot external quality assessment scheme for analysis and reporting of circulating tumour DNA. BMC Cancer 2018;18:804.
208. Lippi G, Simundic AM. The EFLM strategy for harmonization of the preanalytical phase. Clin Chem Lab Med 2018;56: 1660-6.

209. Lippi G, Simundic AM. The preanalytical phase in the era of high-throughput genetic testing. What the future holds. Diagnosis (Berl) 2019;6:73-4.

210. Lippi G, von MA, Cadamuro J, Simundic AM. Blood sample quality. Diagnosis (Berl) 2019;6:25-31.

211. Betsou F, Bilbao R, Case J, Chuaqui R, Clements JA, De SY, et al. Standard PREanalytical Code version 3.0. Biopreserv Biobank 2018. Available at: https://doi.org/10.1089/bio.2017.0109. 